\title{
日本国内における昼間の地表面付近の大気放射量推定法
}

\author{
藤枝 鋼*（気象研究所環境・応用気象研究部） \\ *現所属：気象庁
}

\section{An improved equation for estimating diurnal atmospheric radiation near the surface in}

\section{Japan}

\author{
by
}

\author{
Tsuyoshi Fujieda ${ }^{1^{*}}$
}

\author{
1. Atmospheric Environment and Applied Meteorology Research Department, \\ Meteorological Research Institute, Tsukuba, Japan \\ * Present Affiliation: Japan Meteorological Agency, Tokyo, Japan
}

(Received March 24, 2017; Accepted January 24, 2018; Published February 23, 2018)

\begin{abstract}
It is important to evaluate precisely whether observational data that include screen-level air temperatures could be affected by the environment around meteorological surface observation stations. It is well known that atmospheric radiation (downward long-wave radiation) from the atmosphere and clouds affects the temperature of the ground as well as observational air temperature data, but there are few stations that observe atmospheric radiation. Therefore, various formulas have been proposed and developed to estimate the atmospheric radiation under clear sky conditions that use air temperature and water vapor pressure; these are used in earth surface models to estimate average hourly thermal energy budgets in the planetary boundary layer. It is necessary to verify whether the formulas are applicable for recent data in Japan, because these formulas were developed with data collected at local observation stations during specific periods.

In this study, the accuracy of the familiar formulas used for estimation of diurnal atmospheric radiation under clear sky conditions was evaluated. Results from the formulas were compared with observational data from five stations, namely Sapporo, Tateno (Tsukuba), Fukuoka, Ishigaki Island, and Marcus Island, at which renovated solar and infrared radiation observations commenced on 31 March 2010. It was found that there were noticeable differences between observations and calculations as well as their seasonal variations. Therefore, the coefficients of Brutsaert (1975), which are comparatively theoretical, were adjusted to fit the regional meteorological conditions. The new Brutsaert-type formulas caused the differences and seasonal variations to disappear. Furthermore, in order to be applicable to various meteorological conditions including cloudy skies, the new formula for clear sky conditions was corrected by using sunshine duration and optical air mass. With these corrections, the average of differences between observations and calculations became close to zero.
\end{abstract}

\section{1.はじめに}

地上気象観測所の周辺の観測環境が地上気温等の観 測結果に及ぼす影響を評価することは重要である。こ の要因には様々なものが存在するが、中でも、大気や 雲からの下向き長波長放射（以下、大気放射という）

Corresponding author: Tsuyoshi Fujieda

Japan Meteorological Agency,

1-3-4 Otemachi, Chiyoda-ku, Tokyo 100-8122, Japan.

E-mail: fujieda@met.kishou.go.jp
が地表面温度等に影響を与え、気温の観測結果を左右 することが知られている。しかしながら、大気放射を 観測する地点の数は限られている。このため、気温や 水蒸気圧等の地上気象観測データから晴天時の大気放 射量（下向き長波長放射照度）を推定する様々な計算 式が提案され、陸面モデル等における 1 時間程度の平 均的な大気境界層の熱エネルギー収支の簡易推定など に利用されている。ところが、これらの式は、特定の 地域や過去の限られた期間における観測データに基づ いて作成されていたことから、近年の日本付近の気象 
条件への適用の可能性については、改めて検証する必 要があると思われた。

本研究では、晴天時の大気放射量を推定するために これまでに用いられてきた代表的な計算式について、 2010 年 3 月 31 日から新しい日射放射観測が開始された 札幌、館野 (つくば)、福岡、石垣島及び南鳥島（Marcus 島）の国内の 5 地点における昼間の大気放射量の観測 データに基づいて精度評価を行った。その結果、大気 放射量の観測值と計算值との間に少なくない誤差やそ の季節変動等が確認されたため、各地点の地域特性に 合うように Brutsaert（1975）の式の改良を行い、良好 な結果を得た。さらに、量天時を含む気象条件にも適 用可能となるように、日照時間 (SD: Sunshine Duration) と相対大気路程（相対エアマス）を用いて、晴天時の 推定值を補正する方法を新たに開発し、その精度評価 を行ったので、それらの結果について報告する。

\section{2. 大気放射量の観測と特性}

\section{1 日本国内における放射観測}

気象庁における日射放射観測は、2010 年 3 月 31 日 から、札幌、館野、福岡、石垣島及び南鳥島の国内の 5 地点において、直達日射、散乱日射及び大気放射に観 測要素を拡充して行われている。これらの観測地点は、 高層気象観測を実施していることに加え、それまでの 直達日射観測の継続性と日本の気候区の代表性を考慮 して選定され、全球エネルギー・水循環観測計画 (GEWEX) の副計画の一つである基準地上放射観測網 (BSRN: Baseline Surface Radiation Network) の観測地 点として登録されている (気象庁地球環境 - 海洋部環 境気象管理官, 2012)。

大気放射量については、Kipp \& Zonen 社製の CGR4 赤外放射計を用いて、4.5 42 $\mu \mathrm{m}$ の波長範囲を 1 秒ご とに 24 時間連続で高精度に観測されているが、本研究 では、簡易な式による推定精度等を考慮して、観測值 として、1 時間平均值を用いた。

\section{2 日本付近の大気放射の特性}

大気や雲からの大気放射は、気温や水蒸気量等に対 応した大気や雲からの放射と雲による反射に関係して いる。日本付近の大気中の水蒸気量が、全般に気温の 高い夏季に多く、気温の低い冬季には少ないため、大 気放射量は、夏季に大きく、冬季に小さいという傾向 がある。Fig. 1 に、札幌、館野、福岡、石垣島及び南鳥 島における 2011 年の昼間の地上気温 $\left({ }^{\circ} \mathrm{C}\right)$ の観測值の 時系列図を、Fig. 2 に、各地点における 2011 年の昼間 の地上の水蒸気圧 $(\mathrm{hPa})$ の観測值の時系列図をそれぞ れ示す。札幌は、館野に比べて、年間を通じて気温が 低く水蒸気圧が低い（水蒸気量が少ない）。これに対し て、石垣島や南鳥島などの低緯度の島々では、年間を 通じて高温・高湿で、それらの季節変動は小さい。五
つの地点の気温は、札幌の約 $-10{ }^{\circ} \mathrm{C}$ から館野や福岡の約 $36{ }^{\circ} \mathrm{C}$ ま゙の範囲に、水蒸気圧は、札幌の約 $1 \mathrm{hPa}$ から 石垣島の約 $36 \mathrm{hPa}$ までの範囲に渡っている。

Fig. 3 に 2011 年の昼間の大気放射量 $\left(\mathrm{W} / \mathrm{m}^{2}\right)$ の観測 值の時系列図を示す。大気放射量の值は、気温と水蒸 気圧の季節変動を反映して、夏季に大きく、冬季に小 さい。そして、年間を通じた石垣島と南鳥島の大気放 射量の変動が、札幌、館野及び福岡に比べて小さいの は、気温や水蒸気圧の季節変動が小さいためと考えら れる。

Fig. 4 に、館野における 2011 年の晴天時の大気放射 量 $\left(\mathrm{W} / \mathrm{m}^{2}\right)$ を示す。ここで、本研究では、「日照時間 $(S D) 」 か ゙ 1.0$ の場合を「晴天」として定義した。これ については、第 3.3 節で詳述する。Fig. 4 と Fig. 3 (2) を比較すると、大気放射量は、雲の少ない晴天時に小 さく、雲の多い曇天時には大きくなることがわかる。 このため、一般的に、曇天時を含む大気放射量は、晴 天時の大気放射量の推定式で計算された值に対して、 雲による影響を補正することにより求められている。

\section{3 日本付近の大気の鉛直構造}

Fig. 5 (1) に、国内 5 地点における 00 UTC のラジオ ゾンデによる気温の鉛直プロファイルの平年值（1981 〜2010 年）を示す。比較のため、各地点の気温減率 $\gamma$ を平均して求めた平均気温減率 (赤色の実線) と ICAO 標準大気 (ICAO, 1993) の気温減率 $\gamma$ ICAO $=-6.5{ }^{\circ} \mathrm{C} / \mathrm{km}$ （青色の点線）も、見やすいように適当な間隔をあけ て、直線の傾きで示した。気温減率 $\gamma$ は、地上から高 度 $11 \mathrm{~km}$ 以下の範囲のデータを直線回帰することによ り、回帰直線の傾きから求めた。各地点の気温減率は、 およそ-5.9〜-5.6 ${ }^{\circ} \mathrm{C} / \mathrm{km}$ の範囲で、地域的な差は小さか った（Fig. 5 (2))。

気温減率を 00 UTC と 12 UTC という観測時刻の違い で比較すると、館野と福岡で小さな差が見られるほか は、ほぼ同じであった。むしろ、それよりも ICAO 標 準大気の気温減率との差の方が大きかった。

Fig. 6 （1）に、1981 2010 年の 00 UTC の国内 5 地 点におけるラジオゾンデによる水蒸気の混合比（体積 百万分率 $(\mathrm{PPMV}))$ の鉛直プロファイルを示す。この 図から、水蒸気量が多い順に、石垣島と南鳥島、館野 と福岡、並びに札幌の三つのグループに分けられるこ とがわかる。比較のため、Fig. 6（2）に、様々な放射 伝達モデルの内蔵大気モデルとして用いられることが 多い、米空軍研究所 (AFGL: U.S. Air Force Geophysics Laboratory）の大気モデル（AFGL, 1986）の水蒸気の混 合比 (PPMV) の鉛直プロファイルも示した。石垣島と 南鳥島は、中緯度夏（MLS: Mid-Latitude Summer）に近 く、館野と福岡は、米国標準大気 (US STA: U.S. Standard Atmosphere）に近いことがわかる。札幌については、 中緯度冬（MLW: Mid-Latitude Winter）に近いように見 られるが、札幌の方が高度に対する勾配が急である。 


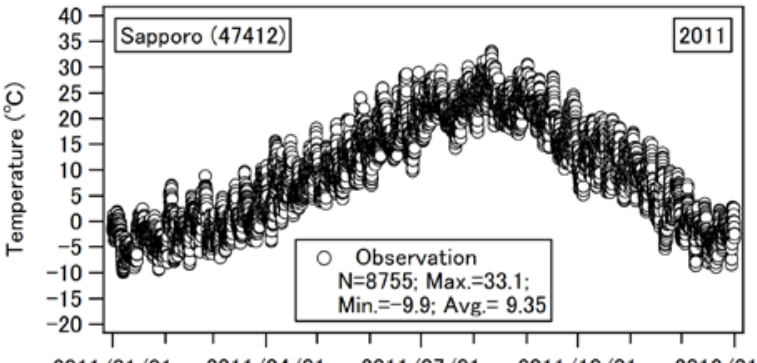

$2011 / 01 / 01 \quad 2011 / 04 / 01 \quad 2011 / 07 / 01 \quad 2011 / 10 / 01 \quad 2012 / 01 / 01$

(1) Sapporo

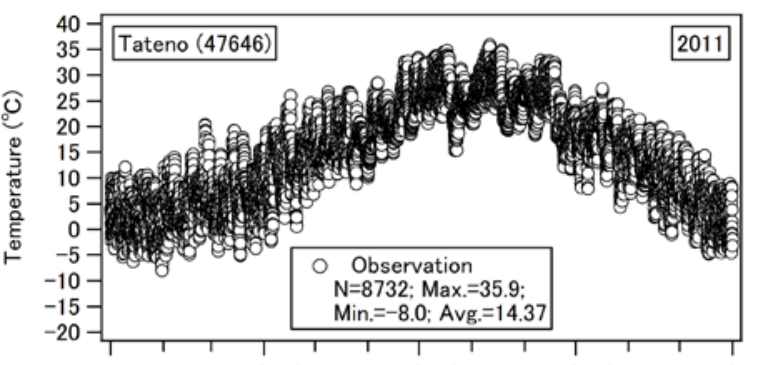

2011/01/01 2011/04/01 2011/07/01 2011/10/01 2012/01/01 Date

(2) Tateno
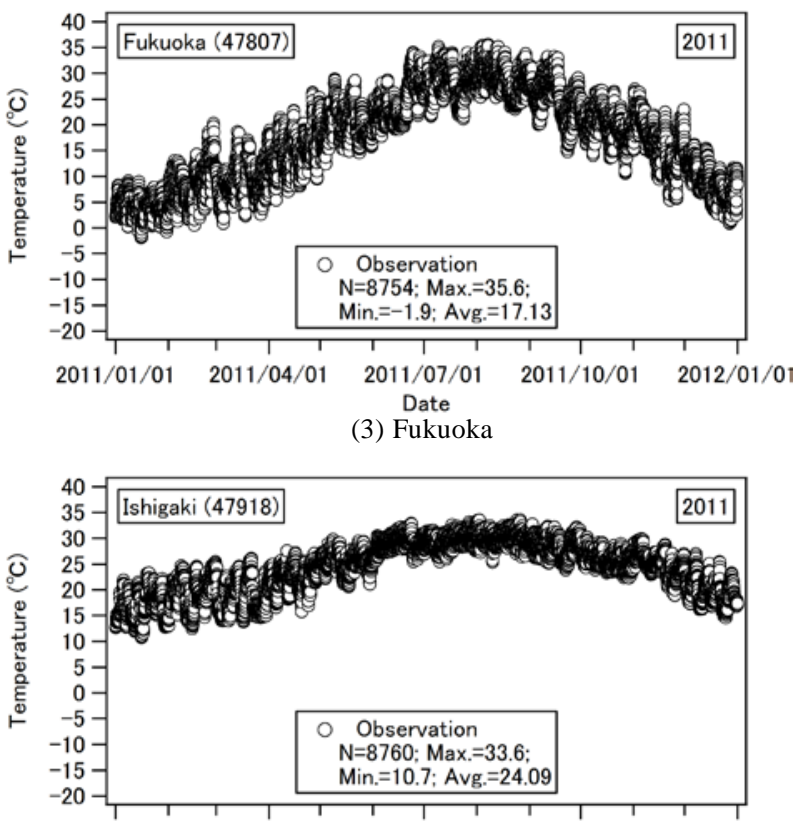

$2011 / 01 / 01 \quad 2011 / 04 / 01 \quad 2011 / 07 / 01 \quad 2011 / 10 / 01 \quad 2012 / 01 / 0$ Date

(4) Ishigaki

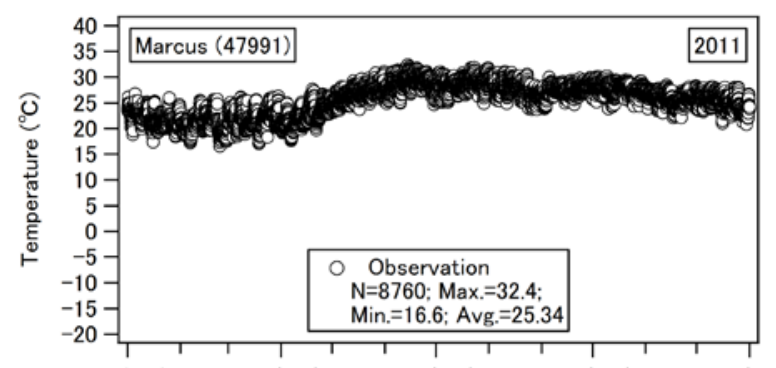

$2011 / 01 / 01 \quad 2011 / 04 / 01 \quad 2011 / 07 / 01 \quad 2011 / 10 / 01 \quad 2012 / 01 / 0$ Date

(5) Marcus

Fig. 1 Diurnal temperatures observed at the domestic surface stations in 2011.

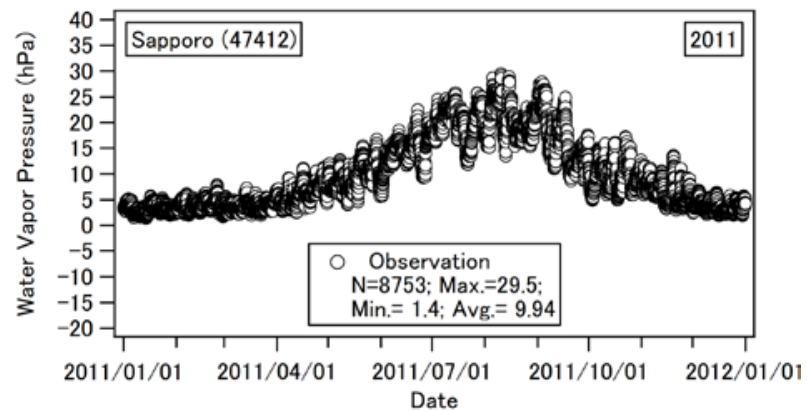

(1) Sapporo

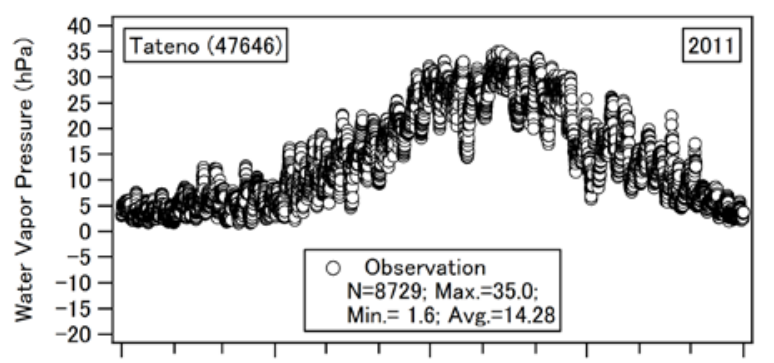

$2011 / 01 / 01 \quad 2011 / 04 / 01 \quad 2011 / 07 / 01 \quad 2011 / 10 / 01 \quad 2012 / 01 / 0$

Date
2) Tateno

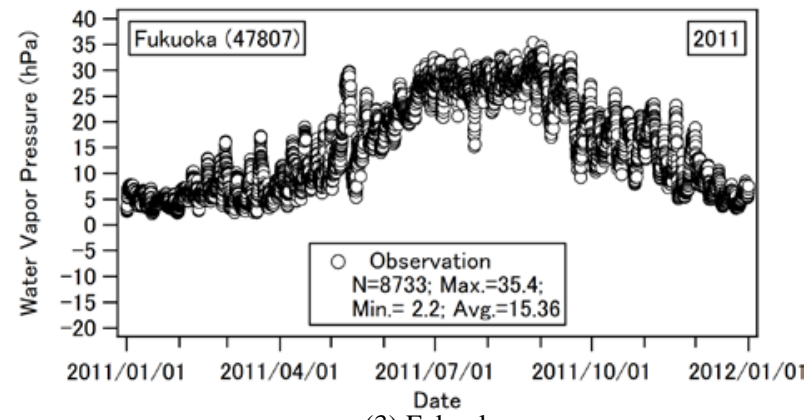

(3) Fukuoka

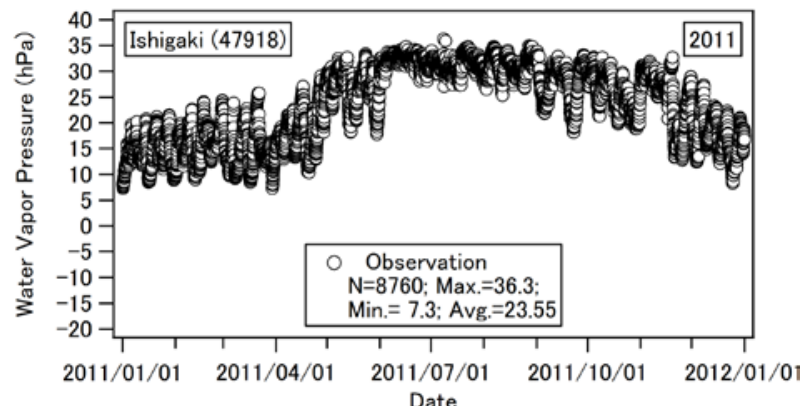

(4) Ishigaki

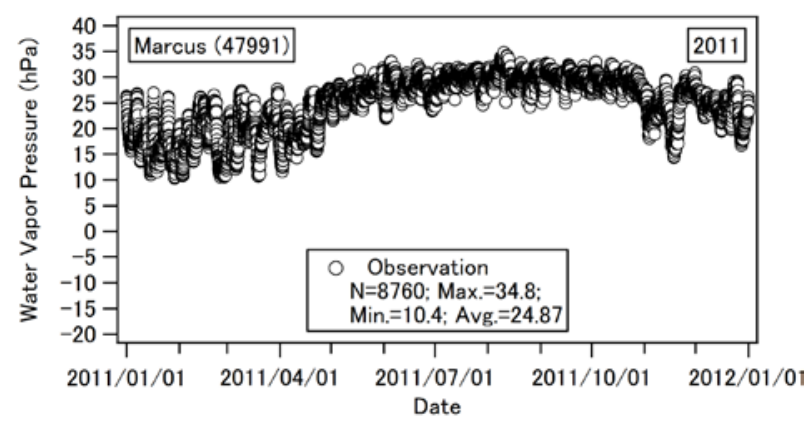

(5) Marcus

Fig. 2 Diurnal water vapor pressures observed at the domestic surface stations in 2011. 


\section{3. 大気放射量の推定法と評価}

\section{1 晴天時における大気放射量の推定}

晴天時における大気放射量 $R_{C L R}$ の簡易な推定法とし て、これまでに様々な式が提案されてきた。これらの 推定法においては、大気放射量が、第一近似として、 大気境界層の平均的な気温に相当する黒体放射と全有 効水蒸気量で表せるということを仮定しており（竹 内・近藤, 1981)、晴天時の大気の射出率 $\varepsilon_{a 0}$ による式の 形で与えられる。すなわち、晴天時の大気の射出率 $\varepsilon_{a 0}$ は、 次式のように、地上気温 $T_{0}(\mathrm{~K})$ における黒体放射に対 寸る晴天時の大気放射量 $R_{C L R}$ の比として定義される。

$$
\varepsilon_{a 0}=R_{C L R} /\left(\sigma T_{0}{ }^{4}\right)
$$

ここで、 $\sigma\left(=5.67 \times 10^{-8} \mathrm{~W} /\left(\mathrm{m}^{2} \mathrm{~K}^{4}\right)\right)$ はステファン・ ボルツマン定数である。

全有効水蒸気量が大気中の水蒸気量（接地層の水蒸 気圧） $e_{0}(\mathrm{hPa})$ と実用的な範囲内で十分な相関を持つ と仮定すると、晴天時の大気の射出率 $\varepsilon_{a 0}$ は、以下のよ うな気温と水蒸気圧の式で表される。代表的な推定式 としては、Ångström and Linke（竹内・近藤, 1981）（以 下、AL)、Brutsaert (1975) (以下、BT) 、 Elsasser and Dines （竹内・近藤, 1981）（以下、ED）、 Idso and Jackson (1969) (以下、IJ)、Prata (1996) (以下、PR)、Satterlund (1979)

(以下、SL)、並びに Yamamoto and Brunt（山本, 1950a; 山本, 1950b）（以下、YB）などがある。

$$
\begin{aligned}
\varepsilon_{a 0} & =0.806-0.236 \times 10^{-0.052 e_{0}} \\
\varepsilon_{a 0} & =1.24\left(e_{0} / T_{0}\right)^{1 / 7} \\
\varepsilon_{a 0} & =0.51+0.22 \log _{10} e_{0} \\
\varepsilon_{a 0} & =1-\left\{1+46.5\left(\frac{e_{0}}{T_{0}}\right)\right\} \\
& * \exp \left\{-\sqrt{1.2+3.0 \times 46.5\left(\frac{e_{0}}{T_{0}}\right)}\right\} \\
\varepsilon_{a 0}= & 1.08\left(1-\exp \left(-e_{0} T_{0} / 2016\right)\right) \\
\varepsilon_{a 0}= & 0.51+0.066 \sqrt{e_{0}} \\
\varepsilon_{a 0} & =1-0.261 \\
& * \exp \left(-7.77 \times 10^{-4}\left(273-T_{0}\right)^{2}\right)
\end{aligned}
$$

$\mathrm{AL} 、 \mathrm{ED} 、 \mathrm{SL} 、 \mathrm{YB}$ 及び IJ は、これまで数多くの書 籍や様々な論文等で取り上げられ、よく利用されてき た経験式である。

これに対して、BTは、比較的放射理論に基づいた方 法で、ICAO 標準大気を仮定し、等気温減率大気（米国 の代表的な数值を使用) を指数関数で近似した水蒸気 の密度プロファイルを用いている。そして、大気の射 出率 (水蒸気と $\mathrm{CO}_{2}$ のスラブ射出率) を、指数関数で 近似するとともに、水蒸気と $\mathrm{CO}_{2}$ による強吸収（平方 根）近似を仮定したスケーリングによって放射伝達式 を解くことにより求めている（Brutsaert, 1975）。

PR は、全球で利用可能となるように、水蒸気圧が大

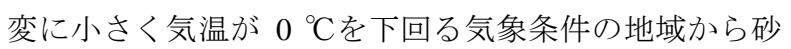
漠のような高温の気象条件の地域までを対象として評

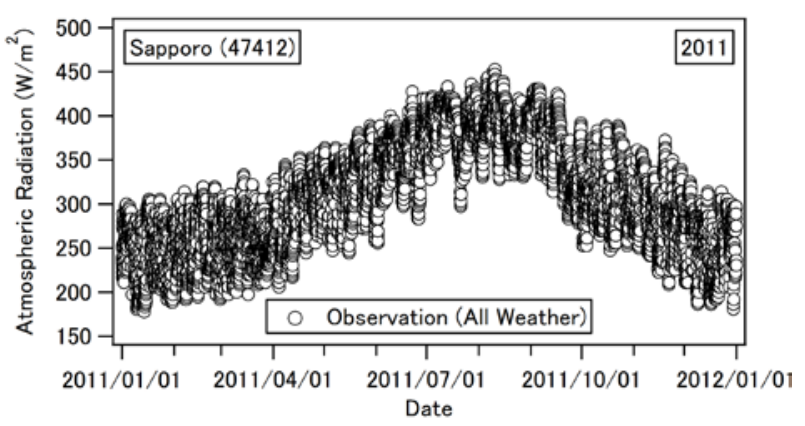

(1) Sapporo

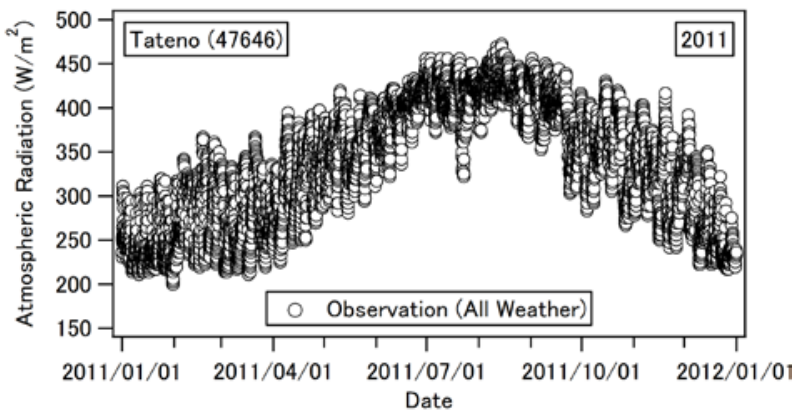

(2) Tateno

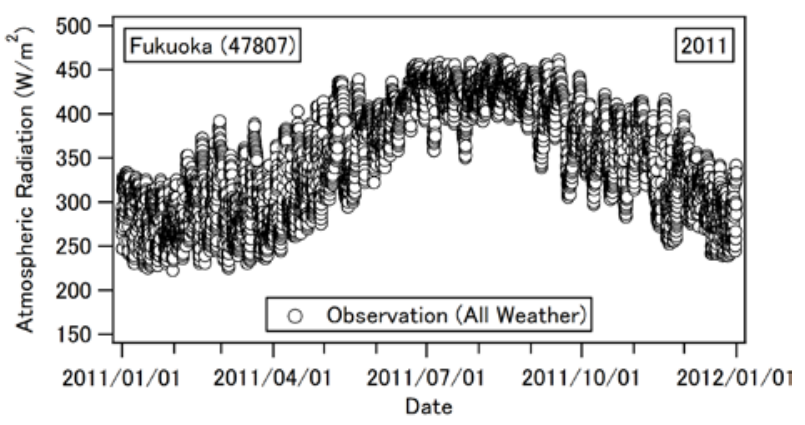

(3) Fukuoka

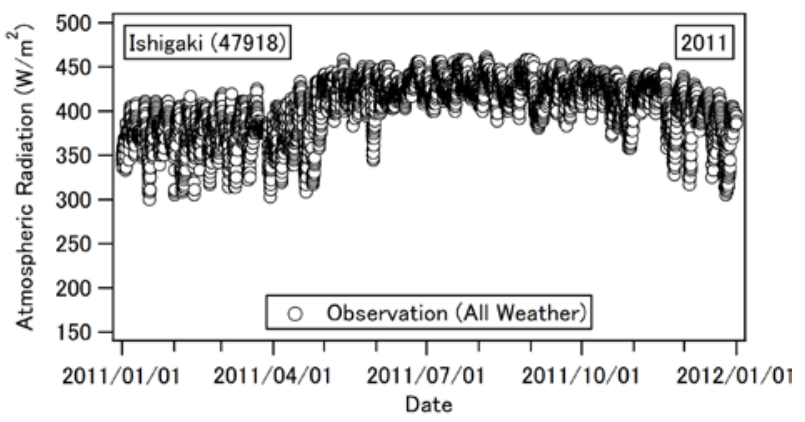

(4) Ishigaki

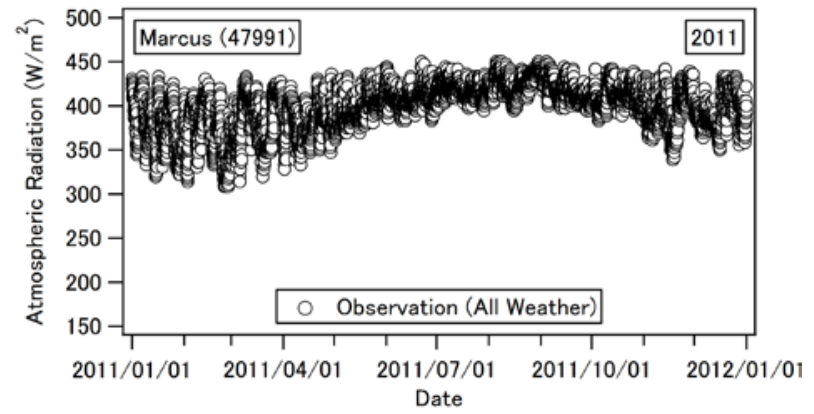

(5) Marcus

Fig. 3 Diurnal downward long-wave radiation observed at the domestic surface stations in 2011. 
価が行われた経験的な式である（Prata, 1996）。

Fig. 7 に、各推定式に基づく、地上気温が $15^{\circ} \mathrm{C}\left(T_{0}=\right.$ $288.15 \mathrm{~K})$ のときの水蒸気圧に対する大気の射出率を 示寸。図が両対数軸で描かれているので、指数関数で 表される BT の式は直線になっている。なお、IJについ ては、推定式のパラメータとして気温だけしか考慮さ れていないことから、評価対象から除外した。

これらの式は、物理的に、（1）任意の気温と水蒸気 圧において理想的な黒体放射を超えない（射出率が 1 を超えない）こと、（2）気温と水蒸気量を計算に考慮 すること、及び (3) 大気中に存在する $\mathrm{CO}_{2}$ によ大気 放射量のベースラインを下回らないことが必要である

(Satterlund, 1979)。

水蒸気が少ない場合、主に $\mathrm{CO}_{2}$ と $\mathrm{O}_{3}$ が射出率に影 響を与える。このため、射出率の下限は、ある一定の 值に近づかなければならない。ところが、BTでは、水

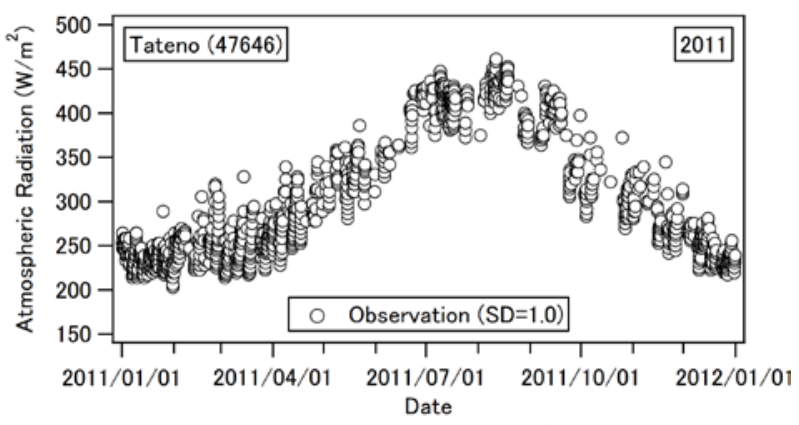

Fig. 4 Diurnal downward long-wave radiation observed at Tateno station under clear sky conditions in 2011.

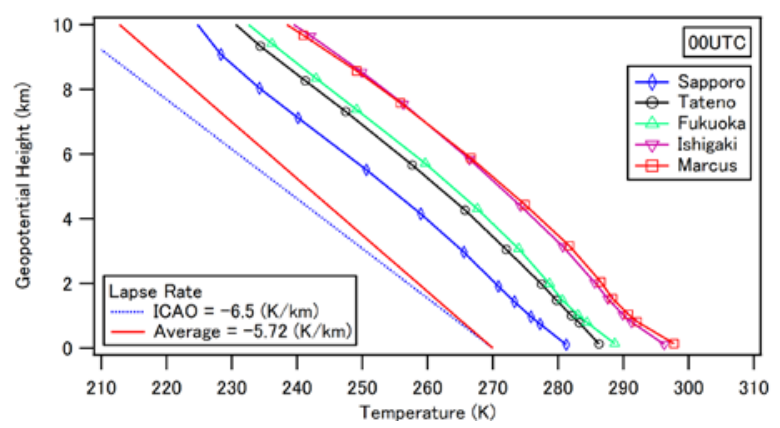

(1)

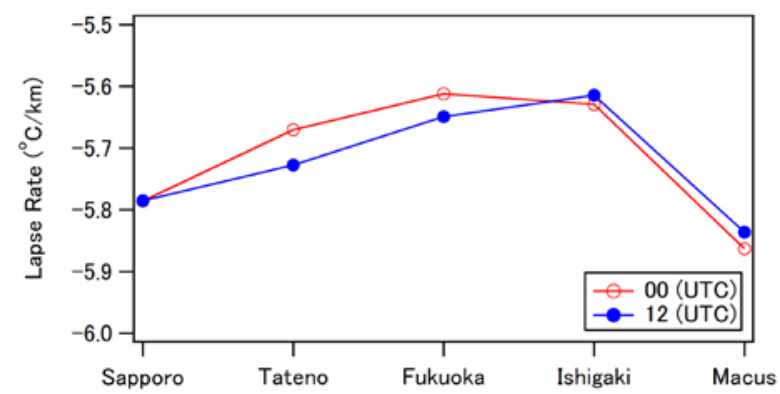

(2)

Fig. 5 (1) Vertical profiles of temperature normals observed by radiosonde at the domestic stations from 1981 through 2010. (2) Lapse rates of temperatures derived from the normals.
蒸気圧が低くなると、射出率が０に近づいてしまう。 これに対して、PR やSL は、水蒸気圧が低い領域で、 射出率がある一定の值に近づくように、そして水蒸気 圧が高い領域で、射出率が 1 を超えないように工夫が 施されている。

この図から、水蒸気圧の低い領域では、AL と YBが 近く、水蒸気圧の高い領域では、BTと YBが近いこと がわかる。PR は、水蒸気圧の高い領域では BT に近い が、水蒸気圧の低い領域では、その他のどれよりも射 出率の下がり方が緩やかになっている。

Crawford and Duchon（1999）が行った ARM 等の観 測データとの比較結果では、BT が優れていることが報 告されている。しかしながら、観測データとしてアメ リカの観測局のデータが用いられているため、前述の ように、気温や水蒸気の鉛直プロファイルを始めとす る気象特性が日本とは異なることから、日本付近の気 象条件において、同様の結果になるかどうかについて は検証する必要があった。

Fig. 8 に、2011〜2013 年における各地点の晴天時の 大気放射量の観測值を、気温の観測值から計算された 黒体放射で除すことにより求めた大気の射出率（式

(1))、及び各推定式（式（2）～式（7））で計算され た大気の射出率を示す。図は両対数軸で描かれている。

AL は全体に過小評価で特に水蒸気圧の高い領域で 過小評価、ED は全体に過小評価で特に水蒸気圧の低い 領域で過小評価、SL は全体に過大評価で、観測值との 対応が悪い。このため、以下では、これらを除く BT、

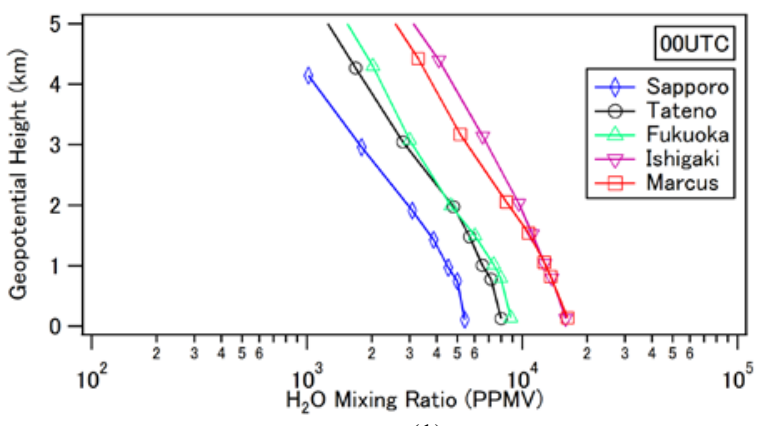

(1)

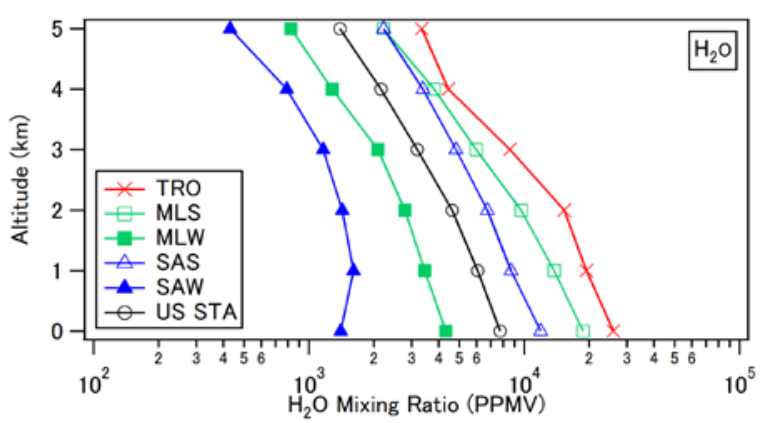

(2)

Fig. 6 (1) Vertical profiles of water vapor normals observed by radiosonde at 00 UTC from 1981 through 2010. (2) Vertical profiles of water vapor mixing ratios in the atmospheric model of AFGL. (TRO: tropical; MLS: mid-latitude summer; MLW: mid-latitude winter; SAS: subarctic summer; SAW: subarctic winter; US STA: U.S. standard atmosphere) 


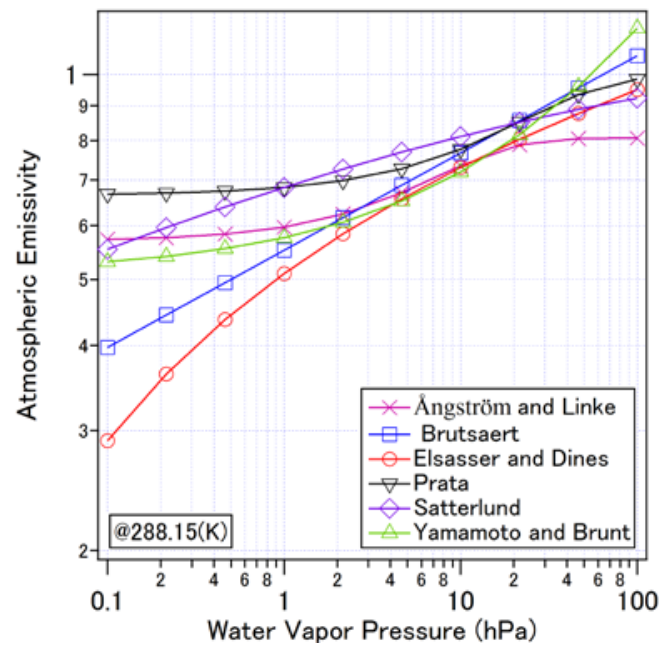

Fig. 7 Comparisons of infrared atmospheric emissivity with water vapor pressure $(\mathrm{hPa})$ at a surface temperature of $288.15 \mathrm{~K}$, calculated by various formulas for the estimation of downward long-wave radiation. Both the vertical and horizontal axes are logarithmic scales.

PR 及び YB の三つの式について詳細な評価を行うこと とした（藤枝, 2014; 藤枝, 2016）。

\section{2 晴天時の大気放射量推定精度の評価}

2011〜2013 年の 3 年間の昼間の地上気温、地上の水 蒸気圧 $(\mathrm{hPa})$ 、及び大気放射量 $\left(\mathrm{W} / \mathrm{m}^{2}\right)$ の 1 時間平均 の観測值を用いて、観測值との対応が比較的良かった BT、PR及び YBについて精度評価を行った。

始めに、全体的な傾向を見るため、2011〜2013 年の 館野における晴天時の大気放射量の観測值に対する YB、BT、PR による計算值の散布図を Fig. 9 に示す。 ここで、実線（黒）は傾き 1 の直線、破線（赤）は回 帰直線である。また、図には、相関係数や回帰直線の 係数のほか、残差（計算值一観測值）の統計量等も併 せて示してある。

館野においては、大気放射量の小さい領域で、YB が過小評価、PR が過大評価であるのに対して、BT に よる計算值は、ほぼ観測值に合っていた。また、大気 放射量の大きい領域では、過大評価である BT や PR に 比べて、YBによる計算值の方が観測值に近かった。し かしながら、館野以外の地点における結果は、館野の 結果とは異なっていた (図略)。Table 1 に、各地点にお ける観測值と計算值の比較結果の一覧を示す。

年間を通じて、館野に比べて気温が高く水蒸気量の 多い石垣島や南鳥島では、BT P PRよりも YB の方が 観測值との差が小さかった。気温が低く水蒸気量が少 ない札幌の結果は、傾向としては、館野と同様であっ た。

BTについては、大気放射量の小さい領域で、札幌が 過小評価、館野が良好、福岡がやや過大評価であった。 大気放射量の大きい領域では、地点によらず過大評価 であった。

PRについては、大気放射量の小さい領域で過大評価、 大気放射量の大きい領域では、やや過大評価または過 大評価であった。一年を通じて水蒸気量が多く、気温

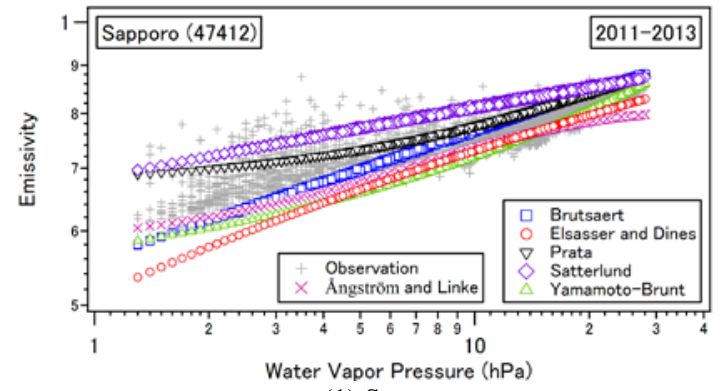

(1) Sapporo

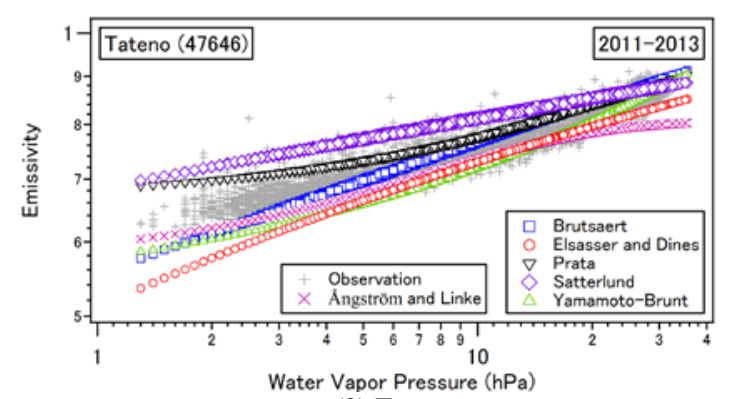

(2) Tateno

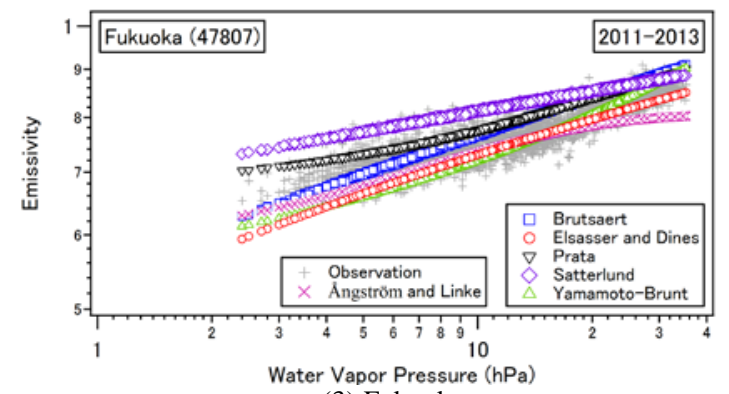

(3) Fukuoka

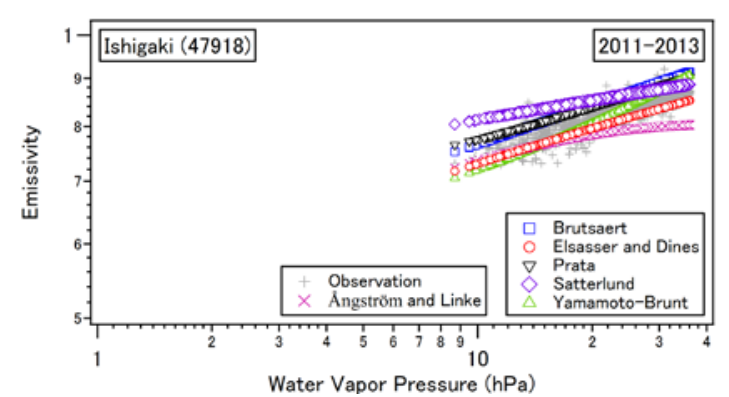

(4) Ishigaki

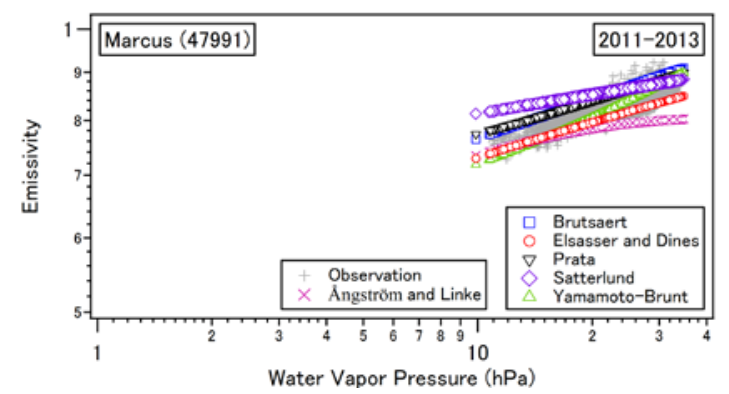

(5) Marcus

Fig. 8 Atmospheric emissivity calculated as the ratio of diurnal observed atmospheric radiation to black body radiation under clear sky conditions during the period from 2011 through 2013. Both the vertical and horizontal axes are logarithmic scales. 


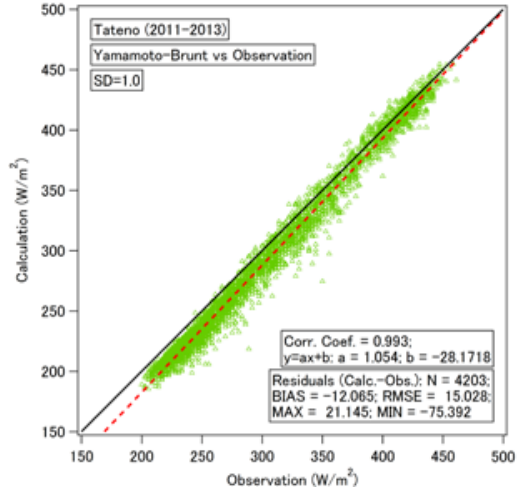

(1) Yamamoto and Brunt

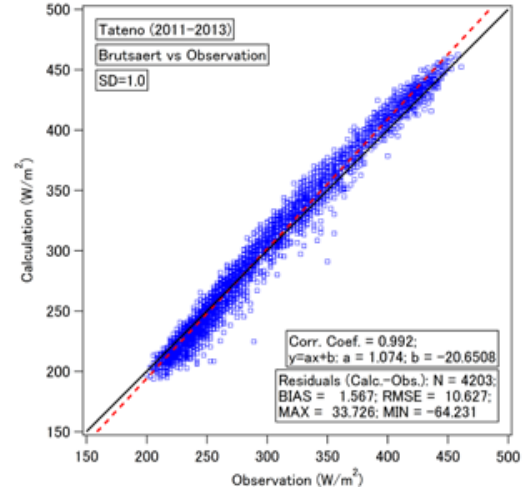

(2) Brutsaert

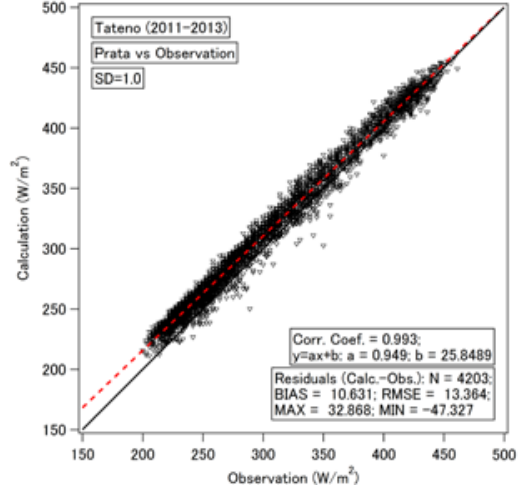

(3) Prata

Fig. 9 Calculated atmospheric radiation versus diurnal observed atmospheric radiation at Tateno under clear sky conditions from 2011 through 2013. The black solid line indicates $y=x$, and the red dotted line is the regression line.

Table 1 Comparison between observations and calculations.

\begin{tabular}{|c|c|c|c|c|c|c|}
\hline \multirow{2}{*}{$\begin{array}{l}\text { Formula } \\
\text { Radiation }\end{array}$} & \multicolumn{2}{|c|}{ Yamamoto and Brunt (YB) } & \multicolumn{2}{|c|}{ Brutsaert (BT) } & \multicolumn{2}{|c|}{ Plata (PR) } \\
\hline & Lower & Upper & Lower & Upper & Lower & Upper \\
\hline Sapporo & $(--)$ & $(-)$ & $(--)$ & $(++)$ & $(++)$ & $(++)$ \\
\hline Tateno & $(--)$ & $(-)$ & $(*)$ & $(++)$ & $(++)$ & $(+)$ \\
\hline Fukuoka & $(*)$ & $(--)$ & $(+)$ & $(++)$ & $(++)$ & $(++)$ \\
\hline Ishigaki & N/A & $(*)$ & N/A & $(++)$ & N/A & $(++)$ \\
\hline Marcus & N/A & $(*)$ & N/A & $(++)$ & N/A & $(++)$ \\
\hline
\end{tabular}

(--): underestimation, (-): slight underestimation, $\left({ }^{*}\right)$ : good, $(+)$ : slight overestimation, $(++)$ : overestimation.

が高く、大気放射量が大きい石垣島と南鳥島は、BT と 同様の傾向であった。

以上のように、良好な結果が得られた式が地点ごと に異なるのは、大気放射量の值の範囲によって、式ご とに推定精度の良否が異なることに起因していると考 えられる。例えば、石垣島や南鳥島のように、年間を 通じて気温が高く水蒸気量が多い地点では、大気放射 量の大きい領域で観測值によく合う YB が良好という 結果になる。

なお、高橋ほか (2012) は、上述の結果とは異なり、 BT や YB 等に比べて、PRによる晴天時の大気放射量の 推定誤差が最も小さいことを報告している。これは、 データ期間が 2012 年 1 月 14 日〜2 月 6 日の 23 日間と 短いこと、及び北海道の苫小牧寒地試験道路 1 地点だ けの結果であることによると思われる。

次に、季節変動を含む観測值と計算值の詳細な対応 関係を見るため、2011年の館野における YB、BT 及び $\mathrm{PR}$ の昼間の晴天時 $(S D=1.0)$ の大気放射量の観測值 に対する計算值の差 (Calc.-Obs.) の時系列図を Fig. 10 に示す。図には、平均䛊差（ME: Mean Error）（以下、 バイアス(Bias)）(式 (9)) と平方根平均二乗誤差 (RMSE: Root Mean Square Error）（式（10））等の統計值も示し た。

$B I A S=\frac{1}{N} \sum($ Calc. - Obs. $)$

$$
R M S E=\sqrt{\frac{1}{N} \sum(\text { Calc. }- \text { Obs. })^{2}}
$$

ここで、Nはデータ数、Calc.は計算值、Obs.は観測值で ある。

YB は、年平均で- $12 \mathrm{~W} / \mathrm{m}^{2}$ を超える負バイアスであっ た。BTのバイアスは約 0.4 でほぼ 0 に近い。PR は、10 $\mathrm{W} / \mathrm{m}^{2}$ 程度の正バイアスであった。YBと BTには、気温 が高く水蒸気量の多い夏季にバイアスが大きく、気温 が低く水蒸気量の少ない冬季にバイアスが小さくなる という季節変動が見られる。これは、気温や水蒸気量 の季節変動が大きい館野では、夏季に大気放射量が大 きく、冬季に大気放射量が小さいため、大気放射量の 值の範囲によって推定精度が異なることに起因してい ると考えられる。

Fig. 11 （1）に、2011年の昼間の晴天時の大気放射量 の観測值に対する計算值のバイアスを示す。YBは、石 垣島と南鳥島で小さな正バイアス、札幌、館野、福岡 で大きな負バイアスであった。BTは、札幌と館野でバ イアスがほぼ 0 であったが、福岡、石垣島及び南鳥島 で大きな正バイアスであった。そして、PRは、地点に よらず、全般に大きな正バイアスであった。

Fig. 11 （2）に、2011年の昼間の晴天時の大気放射量 の観測值に対する計算值の RMSE を示す。YBの RMSE は、札幌、館野、福岡で大きく、石垣島と南鳥島で小 さい。これに対して、BTのRMSEは、札幌と館野で小 さく、福岡、石垣島、南鳥島で大きくなっている。ま た、PRの RMSEは、地点によらず、全般に大きい。2012 年と 2013 年のバイアス及び RMSE の傾向は、2011 年 とほぼ同様であった（図略）。 
以上のように、晴天時の大気放射量の推定精度は、 BT の式による結果が比較的良好であった。しかしなが ら、気温や水蒸気圧が高く、大気放射量の大きい領域 で精度が低下し、これが季節変動として現れていた。 このため、日本国内の各地点の気象特性に合うように、 次のような BT タイプの式の係数の調整を試みた(藤枝, 2015b)。

$$
\varepsilon_{a 0}=R_{C L R} /\left(\sigma T_{0}{ }^{4}\right)=C_{0}\left(e_{0} / T_{0}\right)^{C_{1}}
$$

$2011 \sim 2013$ 年の 3 年間の昼間の晴天時 $(S D=1.0 ）$ に おける大気放射量の観測值 $R_{C L R}$ に合うように、地点ご とに式（11）でフィッティングして、係数 $C_{0}$ 及び $C_{1}$ を Table 2 のおり決定した（藤枝, 2015b; 藤枝, 2016）。 なお、Table 2 には、回帰誤差の推定值（回帰変数の推 定標準偏差）も示した。

Fig. 12 に、式(11)の BT タイプの改良式の係数 (Table 2）の決定に用いた期間（2011～2013 年）とは独立な 2014 年における各地点の昼間の晴天時の大気放射量の 観測值を、気温の観測值から計算された黒体放射で除 すことにより求めた大気の射出率 (式 (1))、及び BT タイプの改良式（式（11））を用いて計算した大気の射 出率を示す。比較のため、BT、PR及び YB の各推定式 （式（3）、式（5）、式（7））から計算された大気の射 出率もプロットした。

BT は、大気放射量の小さい領域で、札幌が過小評価、 館野が良好、福岡がやや過大評価であった。PR は、地 点によらず全体に過大評価であった。そして、YBは、 水蒸気圧の高い領域で良好、それ以外で過小評価であ った。これに対して、BTタイプの改良式は、過大評価 や過小評価にならない中間の特性を示しており、観測 值との対応が良かった。

Fig. 13 （1）に、2014年の館野における晴天時の大 気放射量の観測值と BT タイプの改良式による計算值 との差の時系列図を示す。比較のため、Fig. 13 (2) に、 観測值と BT による計算值との差の時系列図を示す。 Fig. 13（1）から、BTタイプの改良式では、Fig. 13（2） や Fig. 10（2）に見られたような季節変動が軽減されて いることがわかる。

Fig. 14 （1）に、2014 年の晴天時の大気放射量の観測 值に対する計算值のバイアスを、Fig. 14 （2）に、2014 年の晴天時の大気放射量の観測值に対する計算值の RMSE を示す。

Table 2 Regression coefficients and their error estimates (estimated standard deviations for regression coefficients) for Brutsaert-type fitting formulas.

\begin{tabular}{|c|c|c|}
\hline Station & $C_{0}$ & $C_{1}$ \\
\hline Sapporo & $1.04 \pm 0.00$ & $0.092 \pm 0.001$ \\
\hline Tateno & $1.12 \pm 0.00$ & $0.116 \pm 0.001$ \\
\hline Fukuoka & $1.12 \pm 0.00$ & $0.120 \pm 0.001$ \\
\hline Ishigaki & $1.17 \pm 0.00$ & $0.137 \pm 0.001$ \\
\hline Marcus & $1.24 \pm 0.00$ & $0.156 \pm 0.001$ \\
\hline
\end{tabular}

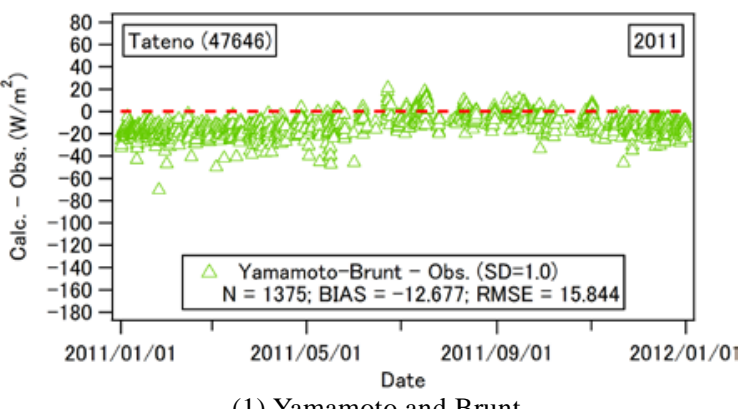

(1) Yamamoto and Brunt

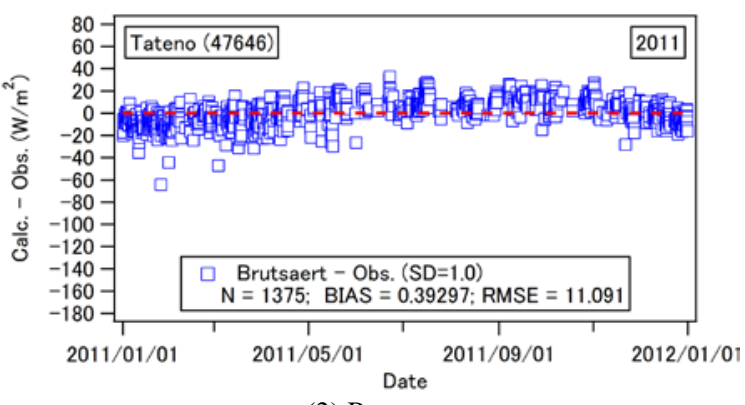

(2) Brutsaert

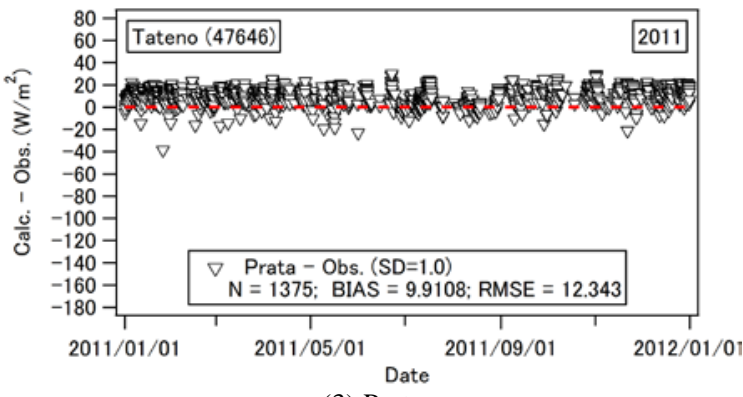

(3) Prata

Fig. 10 Time series of the difference between observed and calculated diurnal atmospheric radiation at Tateno under clear sky conditions in 2011.

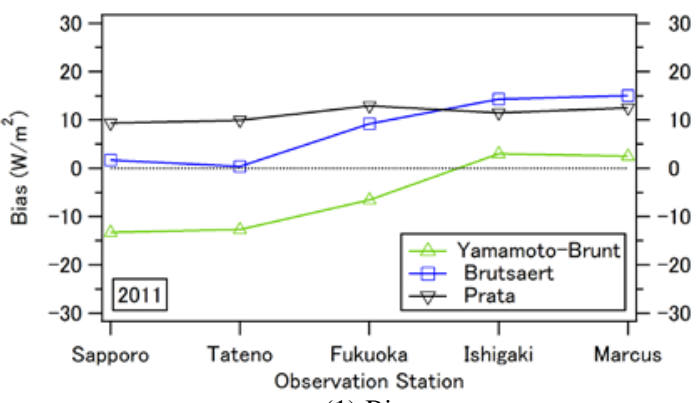

(1) Bias

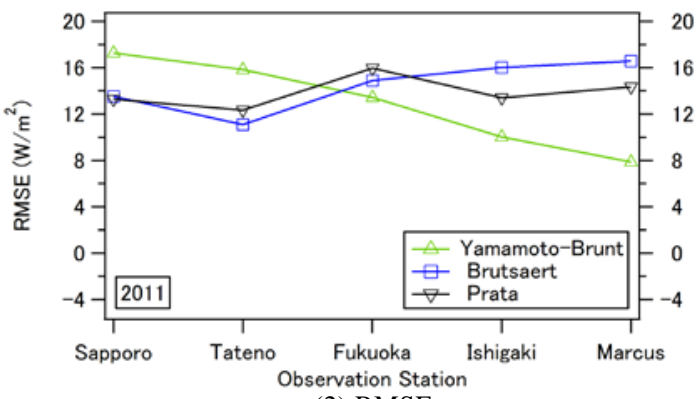

(2) RMSE

Fig. 11 Bias and RMSE for the difference between observed and calculated diurnal atmospheric radiation at the five domestic stations under clear sky conditions in 2011. 


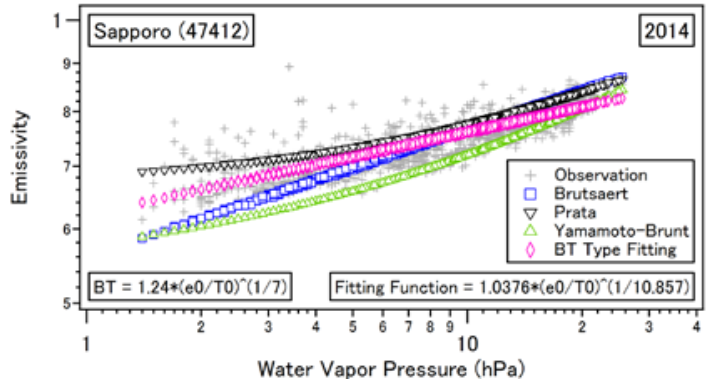

(1) Sapporo

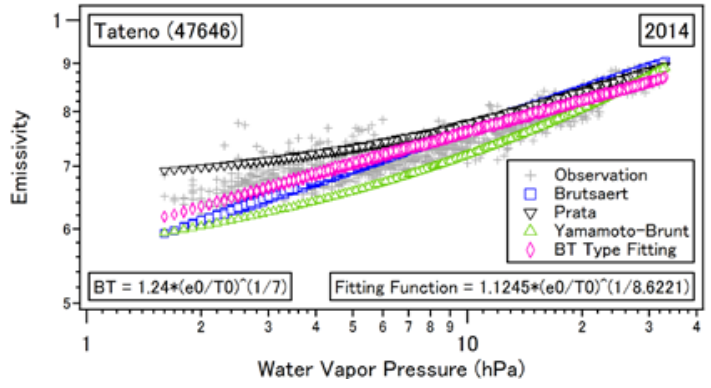

(2) Tateno

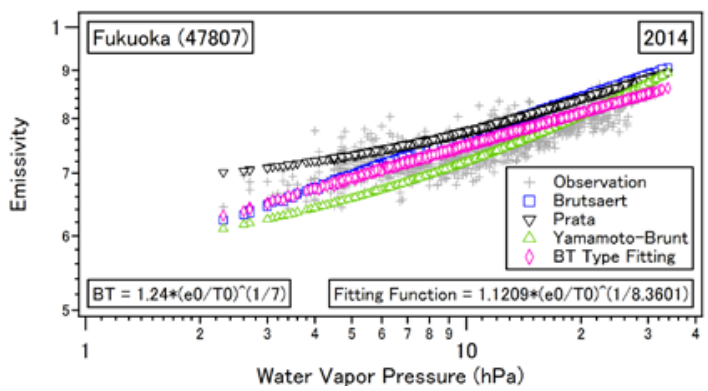

(3) Fukuoka

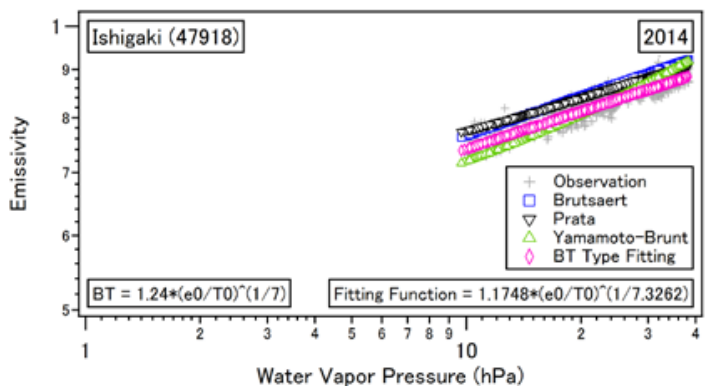

(4) Ishigaki

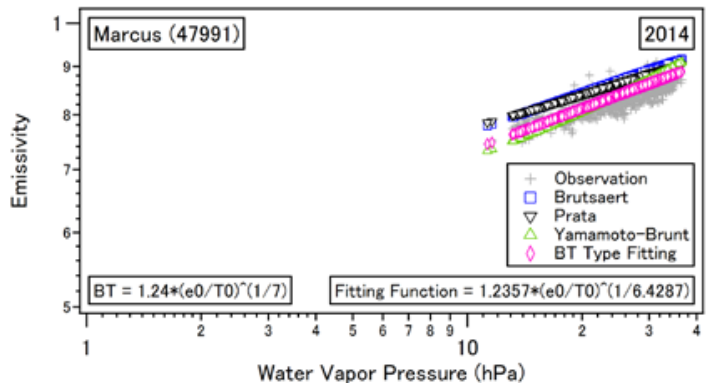

(5) Marcus

Fig. 12 Atmospheric emissivity calculated as the ratio of diurnal observed atmospheric radiation to black body radiation under clear sky conditions in 2014. Both the vertical and horizontal axes are logarithmic scales.

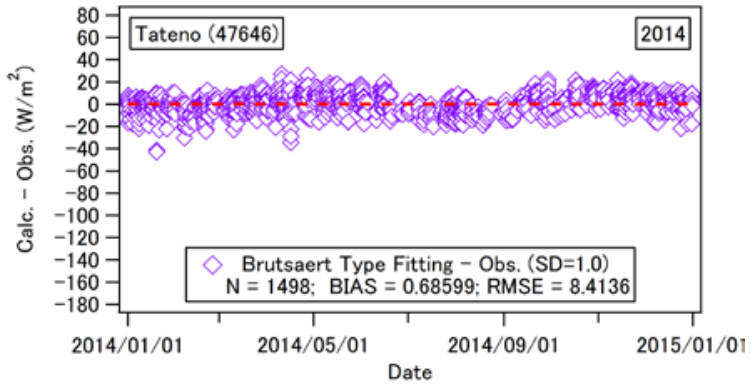

(1)

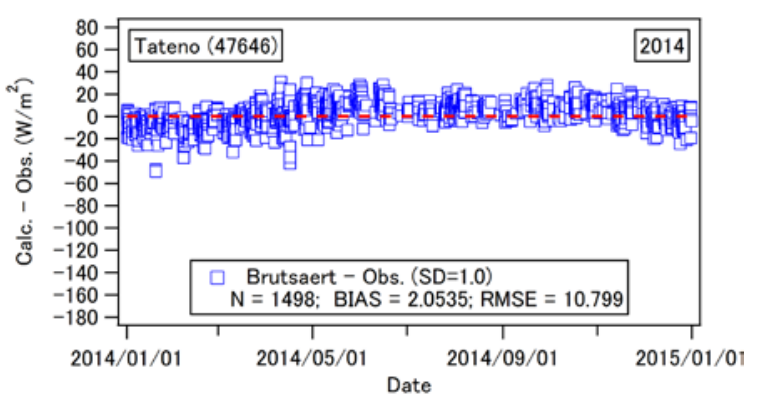

(2)

Fig. 13 Time series of the difference between calculated and observed atmospheric radiation at Tateno under clear sky conditions in 2014. (1) Brutsaert-type fitting formula and (2) Brutsaert formula were used for the calculations.

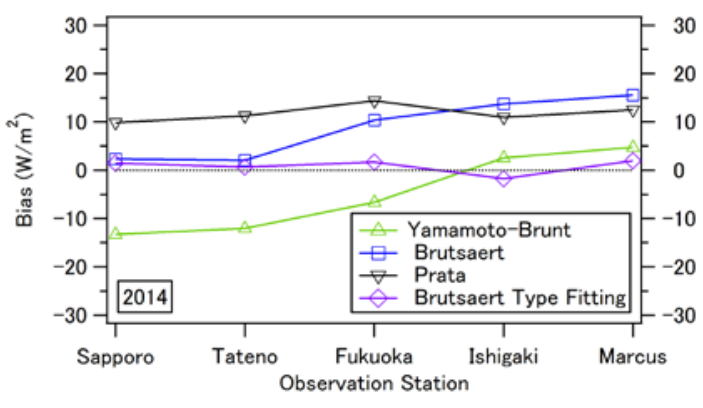

(1)

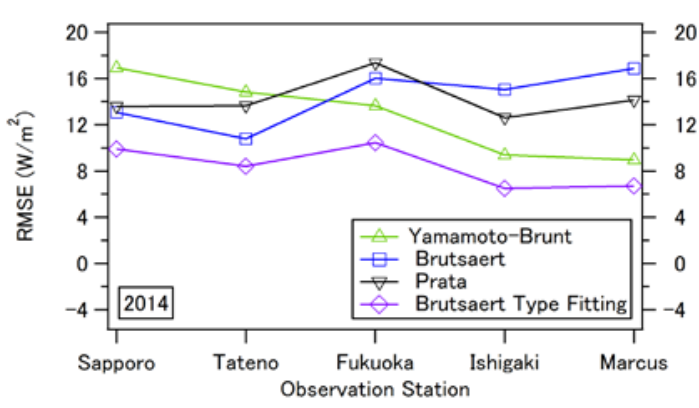

(2)

Fig. 14 (1) Bias and (2) RMSE for the difference between observed and calculated diurnal atmospheric radiation at the five stations under clear sky conditions in 2014. Both bias and RMSE were improved with Brutsaert-type fitting formulas for each station. 
BT タイプの改良式は、地点によらず、バイアスがほぼ 0 に近くなった。RMSEについては、すべての地点で、 BT、PR及び YBに比べて小さくなった。

\section{3 雲による影響の補正方法}

曇天時を含む大気放射量の推定には、晴天時の大気 放射量の推定式で計算した值に対して、雲による影響 を補正する方法がよく用いられている。したがって、 単なる晴天／曇天の判別だけではなく、雲による影響 の程度に応じた大気放射量の増分を見積もる必要があ る。

雲による影響の補正を行うためには、現在天気、雲 量または日射量等の利用が考えられる (Sugita and Brutsaert., 1993; 二宮ほか, 1996; 高橋ほか, 2013)。しか しながら、現在天気と雲量は、観測する地点が気象官 署に限られ、観測の頻度も少ない（有人の場合、地点 によって 1 日 3〜 7 回観測）ことから、毎時の大気放射 量の推定には、利用しづらいと考えられる。また、日 射量については、観測頻度は高いけれども、観測地点 が気象官署に限られるという問題がある。一方、気象 官署やアメダスで毎時観測されている日照時間（SD） は、雲の存在との間に相関のあることが知られている。 このため、本研究では、SDを晴天判別や雲による影響 の補正に用いることとした（藤枝, 2015a）。

水蒸気圧（または湿度）の観測は、現状では、気象 官署及び特別地域気象観測所に限られている。このた め、水蒸気圧の観測がない場合は、最寄りの気象官署 等のデータを利用するか、あるいは、可降水量と地上 における湿度や水蒸気圧との間の相関が高い（近藤, 1997）ことを利用して、GPS 可降水量を用いて地上水 蒸気圧を推定する方法（森ほか, 2006）などの利用も考 えられる。また、現在のところ計画はされていないが、 将来的にアメダスにおいて湿度や水蒸気圧等が観測さ れるようになれば、利用範囲が拡大寸ると考えられる。

日照時間とは、一般的に、直射日光が地表を照射し た時間である。これに対して、アメダスの日照時間は、 直達日射量が $0.12\left(\mathrm{~kW} / \mathrm{m}^{2}\right)$ 以上である時間率 $(0 \sim 1)$ として定義されている。この $0.12\left(\mathrm{~kW} / \mathrm{m}^{2}\right)$ という閾 值は、雲がない場合の日の出のしばらく後や日没のし ばらく前の日射量に相当する（気象庁, 1998）。

Fig. 15 に、2011〜2013 年の国内 5 地点における日照 時間の頻度分布を示す。この図から、すべての地点に おいて、SDが 0.0 と 1.0 の頻度が高く、それらの間の頻 度が低いという傾向があることがわかる。太陽高度の 高い日中の晴天時は、入射する太陽光の放射照度が大 きいため、受光部が完全に飽和する。この場合、光学 的に薄い雲などがかかっていても、 $S D=1.0$ となる可能 性はあるが、本研究では、1 時間平均值を用いているこ となどを考慮して、SD = 1.0の場合を「晴天」として定 義した。

短波長放射は、雲の光学的厚さで決まる特徵と雲が 覆う面積（雲量）を掛け合わせたものになる（早坂, 2014)。太陽の方向に雲が多くなると直達日射が遮られ るため、日照時間は、晴天時の $S D=1.0$ から急速に減少

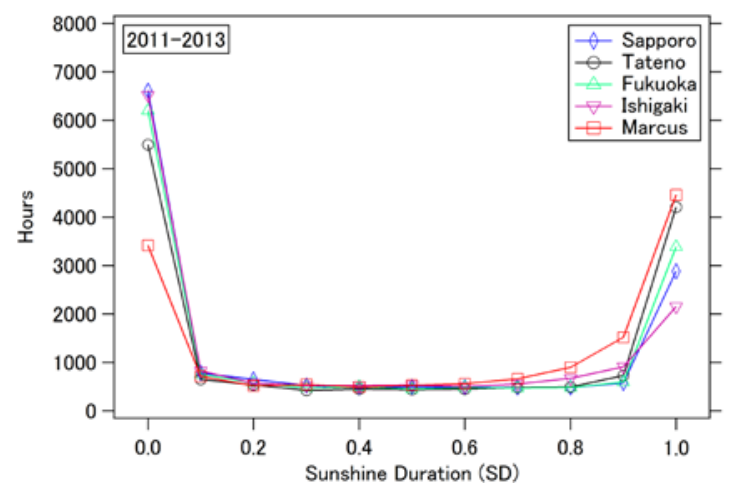

Fig. 15 Histogram of the diurnal Sunshine Duration ( $S D$ ) observed at the stations from 2011 through 2013.

する。そして、日中でも厚い雲に覆われた曇天時は、 $S D=0.0$ となる。

太陽高度が低くなるにつれて、太陽光が大気を通過 する距離が増大するため、直達太陽光の放射照度は緩 やかに低下し、やがて受光部の飽和は解消する。太陽 高度がさらに低くなるとき、すなわち日の出・日の入 の時刻に近い時間帯は、晴れていても薄暗くなるため、 $S D=0.0$ となる。この時間帯には、太陽光が空気の密度 の高い地上付近を長い距離通過するため、太陽高度が 高い時に比べて、放射照度は低下寸る。なお、本研究 では、 1 時間程度の平均的な大気放射量の推定を行うこ とを目的としているため、正時から 1 時間以内に日の 出・日の入となる時間帯のデータ、すなわち日昇後 1 時間または日没前まで 1 時間に満たない日照時間のデ 一夕は、評価の対象から除外した。

地球大気における水蒸気等を含む空気の密度は、高 度が下がるとともに指数関数的に増大する。したがっ て、水蒸気の混合比も指数関数的に増大寸る (Fig. 6)。 また、赤外の下向き有効射出率は、鉛直積算雲水量の 対数にほぼ比例して増大し、数十 $\left(\mathrm{g} / \mathrm{m}^{3}\right)$ 程度で射出 率 1、すなわち黒体に近づくことが知られている (早坂, 2014）。赤外領域においては、雲が多い（射出率が大き い）と大気放射量は大きくなり、雲が少ない（射出率 が小さい）と大気放射量は小さくなる。そして、晴天 時でも、大気の通過距離が長く気圧が高い（赤外の光 学的厚さが大きい）と大気放射量は大きくなる。

以上から、雲や水蒸気を含む大気の影響を補正する ため、 $S D>0$ の場合と $S D=0$ の場合に分けて、水蒸気 を含む空気の量が鉛直方向の何倍になるかということ の指標である相対大気路程（相対エアマス） $m_{r}$ を用い て、BTタイプの改良式による晴天時の射出率に相当す る係数を補正することとした。相対大気路程 $m_{r}$ には、 次式の Kasten の修正式（Kasten and Young, 1989）を用 いた。

$$
m_{r}=1 /\left\{\sin H_{0}+a\left(H_{0}+b\right)^{-c}\right\}
$$

ここで、 $H_{0}$ は太陽高度角 (deg)、各係数は $a=$ $0.50572, b=6.07995, c=1.6364$ である。太陽高度角の 算出方法については、長沢（1999）を参照した。

(1) $S D>0$ の場合

雲により日射が遮られると、SDが小さくなるのに対 
Table 3 Regression coefficients for cloudy sky corrections when $S D>0$.

\begin{tabular}{|c|c|c|c|}
\hline Station & $y_{0}$ & $A$ & pow \\
\hline Sapporo & $1.222 \pm 0.012$ & $-0.244 \pm 0.010$ & $-0.398 \pm 0.035$ \\
\hline Tateno & $1.283 \pm 0.047$ & $-0.293 \pm 0.046$ & $-0.162 \pm 0.033$ \\
\hline Fukuoka & $1.251 \pm 0.017$ & $-0.268 \pm 0.016$ & $-0.296 \pm 0.029$ \\
\hline Ishigaki & $1.129 \pm 0.005$ & $-0.134 \pm 0.005$ & $-0.454 \pm 0.031$ \\
\hline Marcus & $1.129 \pm 0.007$ & $-0.133 \pm 0.007$ & $-0.355 \pm 0.030$ \\
\hline
\end{tabular}

Table 4 Regression coefficients for cloudy sky corrections when $S D=0$.

\begin{tabular}{|c|c|c|c|}
\hline Station & $K_{0}$ & $K_{1}$ & $K_{2}$ \\
\hline Sapporo & $0.9503 \pm 0.0021$ & $-0.0072 \pm 0.0011$ & $0.00028 \pm 0.00011$ \\
\hline Tateno & $0.9594 \pm 0.0024$ & $-0.0055 \pm 0.0015$ & $0.00019 \pm 0.00018$ \\
\hline Fukuoka & $0.9478 \pm 0.0021$ & $-0.0030 \pm 0.0013$ & $-0.00033 \pm 0.00016$ \\
\hline Ishigaki & $0.9553 \pm 0.0013$ & $-0.0030 \pm 0.0009$ & $0.00016 \pm 0.00011$ \\
\hline Marcus & $0.9591 \pm 0.0020$ & $-0.0068 \pm 0.0013$ & $0.00035 \pm 0.00017$ \\
\hline
\end{tabular}

Table 5 Effects of cloudy sky corrections when $S D>0$.

\begin{tabular}{|c|c|c|c|c|}
\hline & \multicolumn{2}{|c|}{ Bias $\left(\mathrm{W} / \mathrm{m}^{2}\right)$} & \multicolumn{2}{c|}{ RMSE $\left(\mathrm{W} / \mathrm{m}^{2}\right)$} \\
\hline Cloudy sky correction & Yes & No & 18.49 & No \\
\hline Sapporo & 1.04 & -17.31 & 13.95 & 19.91 \\
\hline Tateno & 0.61 & -10.32 & 16.85 & 25.13 \\
\hline Fukuoka & 2.47 & -14.37 & 12.40 & 21.79 \\
\hline Ishigaki & -0.33 & -15.56 & 13.51 & 18.74 \\
\hline Marcus & 1.63 & -9.54 & & \\
\hline
\end{tabular}

Table 6 Effects of cloudy sky corrections when $S D=0$.

\begin{tabular}{|c|c|c|c|c|}
\hline & \multicolumn{2}{|c|}{ Bias $\left(\mathrm{W} / \mathrm{m}^{2}\right)$} & \multicolumn{2}{c|}{ RMSE $\left(\mathrm{W} / \mathrm{m}^{2}\right)$} \\
\hline Cloudy sky correction & Yes & No & Yes & No \\
\hline Sapporo & 0.54 & 32.50 & 15.82 & 39.95 \\
\hline Tateno & -2.31 & 24.82 & 14.65 & 32.99 \\
\hline Fukuoka & -0.97 & 31.24 & 14.81 & 38.16 \\
\hline Ishigaki & 0.96 & 28.03 & 10.33 & 34.46 \\
\hline Marcus & -3.41 & 29.22 & 11.26 & \\
\hline
\end{tabular}

して、雲による影響のため、大気放射量は大きくなる。 この影響を補正するためには、SDに対して反比例する ような補正を行うことが考えられる。また、太陽高度 が低くなると、大気を通過する距離が長くなるので、 雲や大気により、太陽光が減衰され、日照計に入射す る光は弱くなる。これを補正するためには、相対大気 路程に比例するような補正を行うことが考えられる。 このような考え方に沿って、2011〜2013 年の大気放射 量の観測值に合うように、晴天時の大気放射量の計算 值 $R_{C L R}$ に対して、式 (13) に示寸式 $f\left(S D, m_{r}\right)$ に様々な 関数形を用いてフィッティングを行い、その結果を用 いて、2014 年のデータで用いて評価を行ったところ、 式（14）に示すような $S D$ と $m_{r}$ の比のべき乗の式を用い たときの結果が最も良好であったので、これを採用し た。式（11）及び Table 2 の係数を用いた BT タイプの 改良式 (射出率) が水蒸気圧のべき乗の式の形をして いるので、式 (13) における式 $f\left(S D, m_{r}\right)$ の関数形とし て、べき乗の形が最も相応しかったと思われる。

$$
\begin{aligned}
& R_{L D}=f\left(S D, m_{r}\right) * R_{C L R} \\
& f\left(S D, m_{r}\right)=y_{0}+A *\left(m_{r} / S D\right)^{p o w}
\end{aligned}
$$

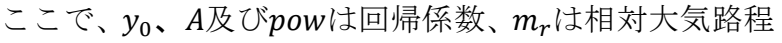
である。各地点の回帰係数の決定結果を Table 3 に示す。 (2) $S D=0$ の場合

太陽高度の高い日中であっても、厚い雲に覆われる ような晴天のときは、 $S D$ は 0 に近づく。雲水量（雲水 量）の多い厚い雲は、黒体（射出率＝1）に近い振る舞 いをするので (早坂, 2014)、 $R_{L D}$ は黒体放射 $\left(\sigma T_{0}{ }^{4}\right)$ に 近いと考えられる。太陽高度が低いため、大気の通過 距離が長くなることにより、SDが過小になる可能性を 考慮して、黒体放射に対して相対大気路程 $m_{r}$ で補正す ることが考えられる。このため、式（15）のように、 黒体放射に対して、関数 $f\left(m_{r}\right)$ で補正した。 $f\left(m_{r}\right)$ とし ては、式（16）のように、 $m_{r}$ の 2 次の回帰式とし、大 気放射の観測值に合うようにフィッティングを行い、 係数を決定した。

$$
\begin{aligned}
& R_{L D}=f\left(m_{r}\right) *\left(\sigma T_{0}{ }^{4}\right) \\
& f\left(m_{r}\right)=K_{0}+K_{1} * m_{r}+K_{2} *\left(m_{r}\right)^{2}
\end{aligned}
$$

ここで、 $K_{0} 、 K_{1}$ 及び $K_{2}$ は回帰係数、 $m_{r}$ は相対大気路程 である。各地点の回帰係数を Table 4 に示す。なお、 3 次の回帰式も試みたが、 2 次の回帰式による結果の方が 


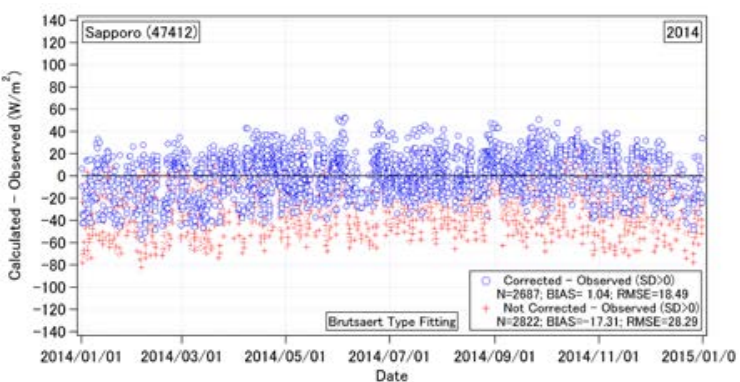

(1) Sapporo

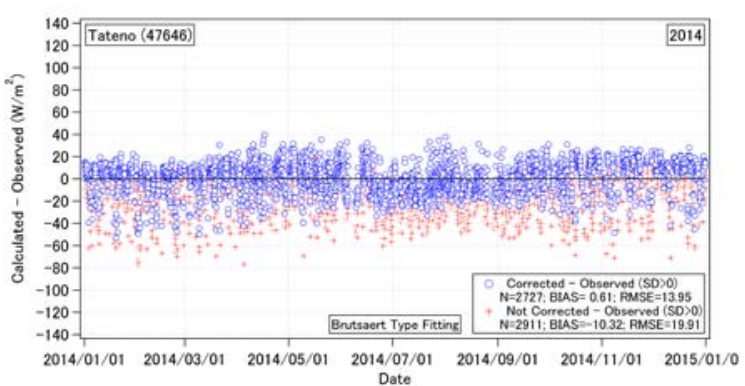

(2) Tateno

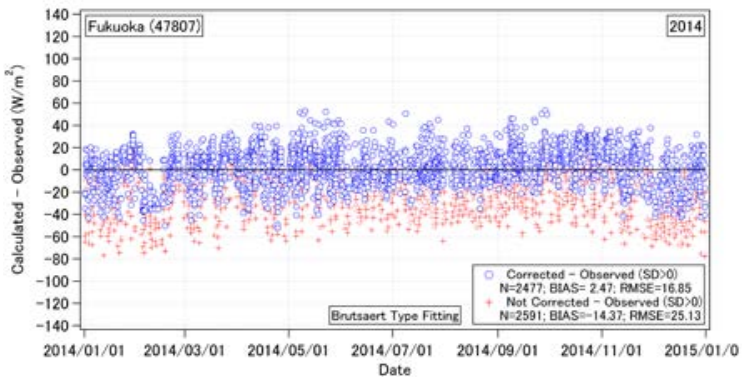

(3) Fukuoka

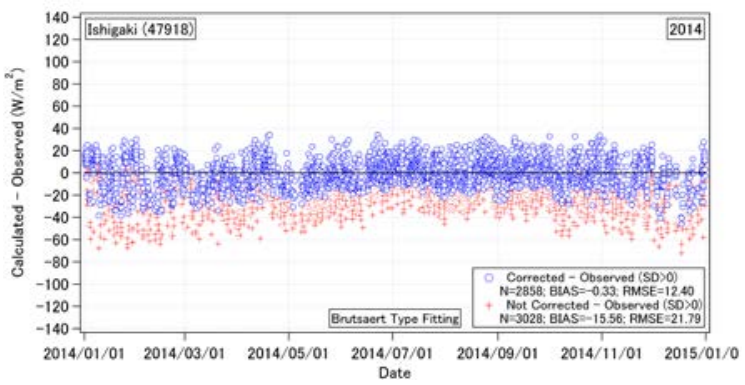

(4) Ishigaki

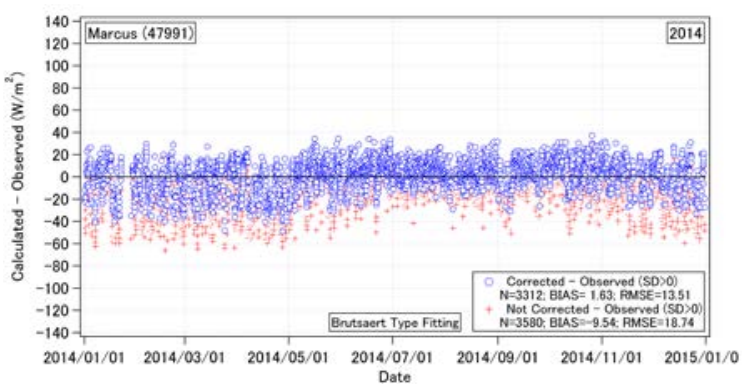

(5) Marcus

Fig. 16 Time series of the difference between observed and calculated diurnal atmospheric radiation in 2014 Brutsaert-type fitting formulas were used for the calculations. The cloudy sky correction was applied (blue circles) or not applied (red crosses) when $S D>0$.

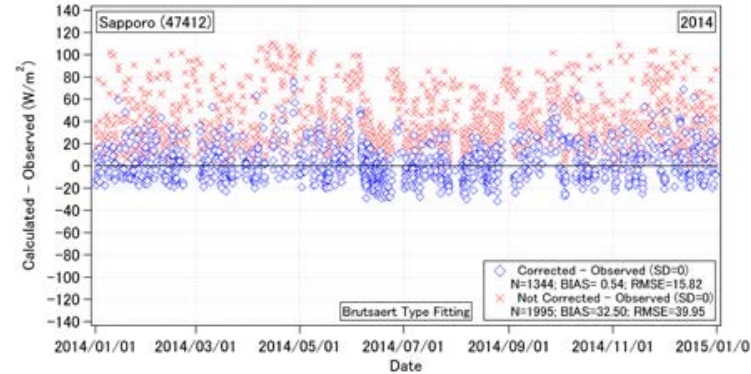

(1) Sapporo

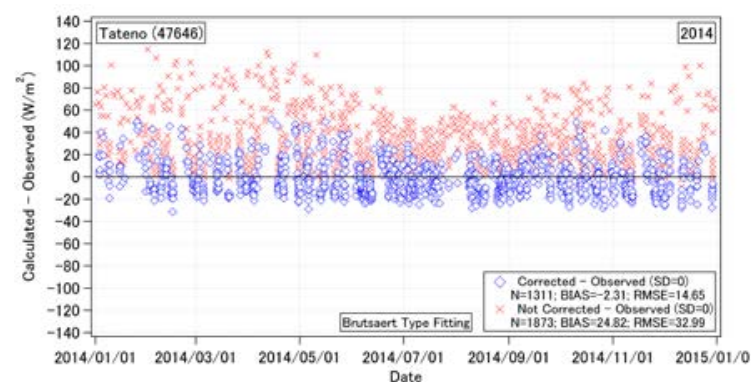

(2) Tateno

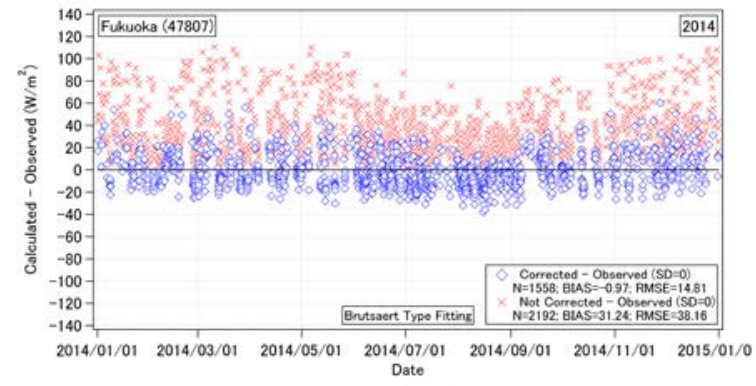

(3) Fukuoka

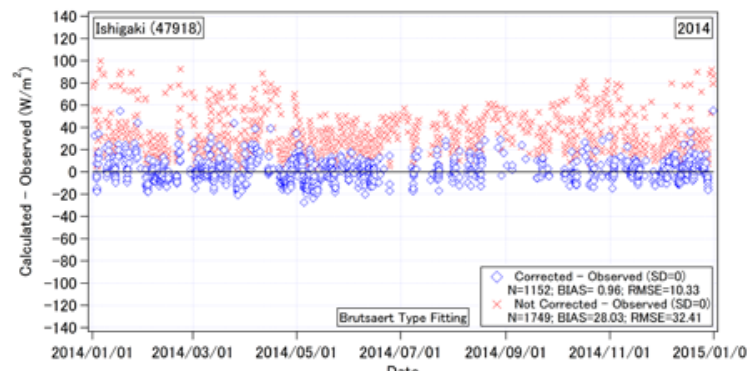

(4) Ishigaki

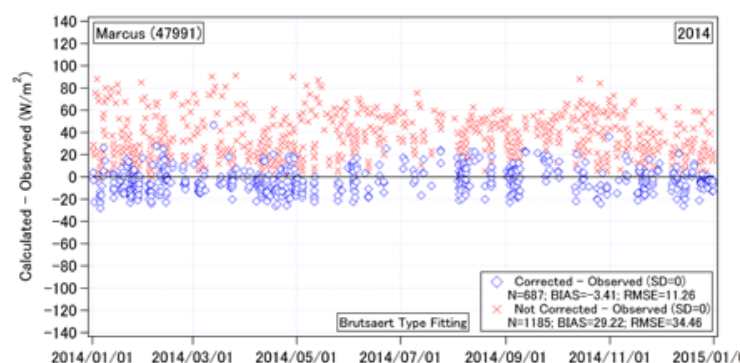

(5) Marcus

Fig. 17 Time series of the difference between observed and calculated diurnal atmospheric radiation in 2014. Brutsaert-type fitting formulas were used for the calculations. The cloudy sky correction was applied (blue diamonds) or not applied (red crosses) when $S D=0$. 
良かった。

\section{4 雲による影響の補正の評価}

Fig. 16 に、 $S D>0$ の場合の雲による影響を補正した とき（青）と補正しないとき（赤）の 2014 年の各地点 における大気放射量の計算值と観測值との差の時系列 図を示す。同様に、 $S D=0$ の場合の時系列図を Fig. 17 に示す。また、 $S D>0$ の場合のバイアス及び RMSEの 一覧を Table 5 に、同様に、 $S D=0$ の場合の一覧を Table 6 に示す。そして、Fig. 18 に、これらのプロット図を示 した。

これらの図表から、SD>0と $S D=0$ のそれぞれの場 合において、地点により多少のばらつきは見られるが、 バイアスがほぼ 0 になり、雲による影響の補正が適切 に行われていることがわかる。また、雲による影響の 補正を行ったことにより，RMSE が $10 \mathrm{~W} / \mathrm{m}^{2}$ 台まで減 少している．なお、晴天時の大気放射量の推定式の係 数が地点ごとに最適化されていることにより、バイア スとRMSEの地点による差は小さくなっている。

\section{4. まとめ}

地上の気温と水蒸気圧を用いた昼間の晴天時の大気 放射量の推定法について、国内 5 地点の観測值と比較 することにより評価した。地上の気温と水蒸気量だけ から推定した射出率としては、BT、YB とも概衫観測 值に合っていたが、次のような特徴があった。

気温が低く水蒸気量が少ない札幌では、YBよりも BT の方が、観測值によく合っていた。館野の結果は、 傾向としては、札幌と同様であった。これに対して、 年間を通じて、札幌や館野よりも気温が高く水蒸気量 の多い石垣島や南鳥島では、BT と YB は同程度か、む しろ YBの方が観測值との差が小さかった。福岡の結果 はそれらの中間であった。

観測地点によって、気温や水蒸気量の範囲や季節変 動が異なった。そして、射出率（または大気放射量） の推定精度には、特に水蒸気量が影響していると考え られた。計算值の誤差の原因として、BT については、 現実の大気の気温や水蒸気の分布が標準大気モデルか ら乘離していることや標準的な気温減率 $\gamma=-6.5{ }^{\circ} \mathrm{C}$ $/ \mathrm{km}$ と差があることのほか、気温の計算において、計算 上の便宜から、単純に指数関数で近似していることに 起因する対流圏上層の気温の過大評価も考えられる。 また、YBについては、2010年 3 月に新たに開始された 気象庁における国内 5 地点の日射放射観測においては、 測器の高精度化と温度特性を考慮した測器の較正が図 られた (気象庁地球環境・海洋部環境気象管理官, 2012) ため、気候特性の変化だけでなく、経験的な係数を決 定する際に用いられた過去のデータの特性との間に差 異が生じたことも考えられる。

BT による計算值の誤差の特性には、季節変動が存在 した。このため、晴天時の大気放射量を推定する Brutsaert の式の係数を、2011〜2013 年の国内 5 地点の 観測值に合うように調整した。そして、2014 年のデー タを用い、計算值を観測值と比較することにより評価

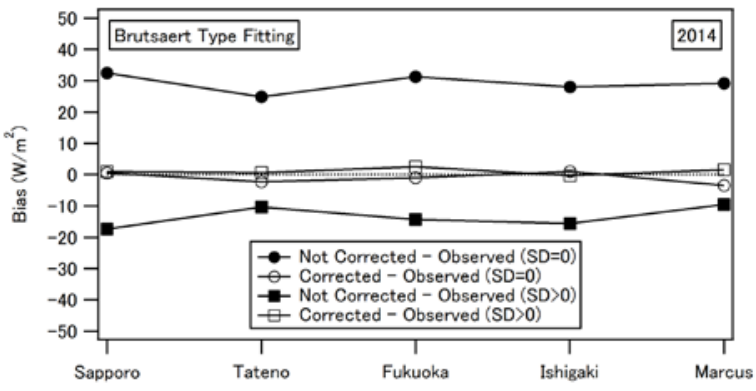

(1)

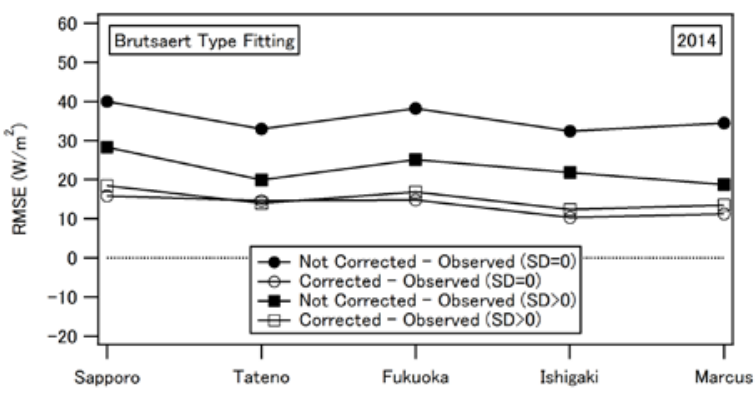

(2)

Fig. 18 (1) Bias and (2) RMSE for the difference between observed diurnal atmospheric radiation and calculated radiation with Brutsaert-type fitting formulas at the five stations under various meteorological conditions including cloudy skies in 2014. The cloudy sky correction was applied (outlined) or not applied (filled) when $S D=0$ (circle) or $S D>0$ (square)

した。その結果、札幌、館野、福岡では、放射量の小 さい領域の過小評価と放射量の大きい領域の過大評価 がほぼ解消され、誤差の季節変動が現れなくなった。

さらに、曇天時を含む大気放射量を推定するための 新たな手法を提案し、2014 年の国内 5 地点の観測值を 用いて評価した。その結果、観測值とのバイアスは、0 付近まで補正された。また、RMSE については、地点 や条件により 10〜 $19 \mathrm{~W} / \mathrm{m}^{2}$ 程度まで減少した。

以上のように、従来の方法に比べて、日本の気候特 性によく合った、晴天時や曇天時を含む昼間の地表面 付近の大気放射量の簡易推定法を開発した。今後の課 題としては、夜間における推定方法の検討が必要と考 えている。

\section{謝 辞}

大気放射量の 1 時間平均值のデータについては、高 層気象台から提供を受けた。ここに、データ提供に際 して様々な労をお取り頂いた、高層気象台観測第二課 居島 修主任研究官に感謝申し上げる。

\section{参考文献}

AFGL, 1986: AFGL Atmospheric Constituent Profiles (0-120km), AFGL-TR-86-0110, 43p.

Brutsaert, W., 1975: On a Derivable Formula for Long-wave Radiation from Clear Skies, Water Resour. Res., 11, 
742-744.

Crawford, T. M. and C. E. Duchon, 1999: An Improved Parameterization for Estimating Effective Atmospheric Emissivity for Use in Calculating Daytime Downwelling Longwave Radiation, J. Appl. Meteorol., 38, 474-480.

藤枝鋼, 2014: 日本国内における地表面付近の下向き長波長放 射量推定に関する評価, 気象学会秋季大会予稿集, D303, 410.

藤枝鋼, 2015a: 曇天時を含む地表面付近の下向き長波長放射 量の推定, 気象学会春季大会予稿集, P124, 112.

藤枝鋼, 2015b: 日本国内における地表面付近の下向き長波長 放射量推定法の改良, 気象学会秋季大会予稿集, P303, 383.

藤枝鋼, 2016: 日本国内における地表面付近の下向き長波長放 射量推定法の改良 (その 2), 気象学会秋季大会予稿集, P132, 199.

早坂忠裕, 2014: 雲の放射特性の基礎, 低温科学, 72, 145-150.

ICAO, 1993: Manual of the ICAO Standard Atmosphere, Third Edition, Doc 7488/3, 14p.

Idso, S. B. and R. D. Jackson, 1969: Thermal Radiation from the Atmosphere, J. Geophys. Res., 74, 5397-5403.

Kasten, F. and A. T. Young, 1989: Revised Optical Air Mass Tables and Approximation Formula, Appl. Optics, 28, 4735-4738.

気象庁, 1998: 気象観測の手引き, 第 8 章日照時間, 43-45.

気象庁地球環境 - 海洋部環境気象管理官, 2012: 新しい日射放 射観測の開始について, 測候時報, 79, 15-37.

近藤昭彦, 1997: 可降水量と地上水蒸気圧の関係, 水文・水資源 学会誌, 10, 367-370.

森牧人, 三森崇道, 平松和昭, 四ヶ所四男美, 2006 : GPS 可降水
量を用いた地上水蒸気圧の推定, 農業土木学会論文集, 242, 91-97.

長沢工, 1999 : 日の出 - 日の入りの計算一天体の出没時刻の求 め方, 地人書館, $160 \mathrm{p}$.

二宮秀與, 赤坂裕, 松尾陽, 1996: AMeDAS のデータを用いた時 刻別大気放射量の推定法, 空気調和・衛生工学会論文集, 60, 133-144.

Prata, A. J., 1996: A New Long-wave Formula for Estimating Downward Clear - sky Radiation at the Surface, Q. J. R. Meteorol. Soc., 122, 1127-1151.

Satterlund, D. R., 1979: An Improved Equation for Estimating Long-wave Radiation from the Atmosphere, Water Resour. Res., 15, 1649-1650.

Sugita, M. and W. Brutsaert, 1993: Cloud Effect in the Estimation of Instantaneous Downward Longwave Radiation, Water Resour. Res., 29, 599-605.

高橋尚人, 川端優一, 徳永ロベルト, 石井吉之, 2012: 晴天時に おける大気放射量推定に関寸る研究, 雪水研究大会, 福 山市, 2012.9.23-27, C4-2.

高橋尚人, 川端優一, 藤本明宏, 徳永ロベルト, 石井吉之, 2013: 量天時における大気放射量推定に関する研究, 雪氷研 究大会, 北見市, 2013.9.17-21, A4-9.

竹内清秀, 近藤純正, 1981: 大気科学講座 1 「地表に近い大気」, 3.2.2 地表面における大気放射, 東京大学出版会, 86-88.

山本義一, 1950a: 夜間輻射について（第 1 報 理論的考察）, 気 象集誌, 28, 1-11.

山本義一, 1950b: 夜間輻射について（第 2 報 数值計算）, 気象 集誌, 28, 11-20.

\title{
日本国内における昼間の地表面付近の大気放射量推定法
}

\author{
藤枝 鋼*（気象研究所環境・応用気象研究部）
}

*現所属：気象庁

地上気象観測所の周辺の観測環境が地上気温等の観測結果に及ぼす影響を評価することは重要である。特に、大気や 雲からの大気放射（下向き長波長放射）が地表面温度等に影響を与えることにより、気温の観測結果を左右することが 知られている。しかしながら、大気放射を観測する地点の数は限られている。このため、気温や水蒸気圧等の地上気象 観測データから晴天時の大気放射量（下向き長波長放射照度）を推定する様々な計算式が提案され、陸面モデル等にお ける 1 時間平均程度の大気境界層の熱エネルギー収支の簡易推定などに利用されている。ところが、これらの式は、特 定の地域や過去の限られた期間における観測データに基づいて作成されていたことから、近年の日本付近の気象条件一 の適用の可能性については、改めて検証する必要があると思われた。

本研究では、晴天時の大気放射量を推定するためにこれまでに用いられてきた代表的な計算式について、2010年 3 月 31 日から新しい日射放射観測が開始された札幌、館野（つくば）、福岡、石垣島及び南鳥島（Marcus 島）の国内の 5 地 点における昼間の大気放射量の観測データに基づいて精度評価を行った。その結果、大気放射量の観測值と計算值との 間に少なくない誤差やその季節変動等が確認された。このため、各地点の地域特性に合うように、比較的放射理論に基 づいた式である Brutsaert（1975）の式の係数を改良した新しい式を適用した。そして、誤差の季節変動が現れなくなる などの良好な結果を得た。さらに、曇天時を含む気象条件にも適用が可能となるように、日照時間と相対大気路程（相 対エアマス）を用いて、晴天時の推定值を補正する方法を新たに開発し、精度評価をしたところ、計算值と観測值との 差の平均值がほぼ 0 になるなどの良好な結果を得た。 